\title{
研磨材粒度の新しい外国規格 $(2)$
}

遠藤幸雄・尾田弘文

\section{6. 粒度測定方法}

6.1 網粒度の測定

6.1.1 標準砂——網粒度測定の 対照規準として用い られる標準砂はつぎによる.

6.1.1.1 熔融アルミナ，炭化珪素およびガーネット 用:

\begin{tabular}{|c|c|c|}
\hline \multirow{2}{*}{ 粒 度 } & \multirow{2}{*}{ 研磨材の種類 } & 標準 砂1) \\
\hline & & 年月日 \\
\hline-2 & 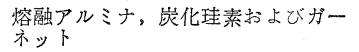 & $3 / 12 / 52$ \\
\hline $5 / 0-180$ & 熔融アルミナ & ……同……. 8/5/52 \\
\hline $0-180$ & 炭化珪素およびガーネット………... & 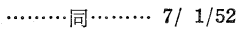 \\
\hline $4 / 0-150$ & 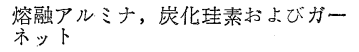 & …局 \\
\hline $3 / 0-120$ & 熔融アルミナおよご炭化珪素.......... & 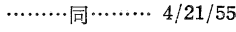 \\
\hline $3 / 0-120$ & 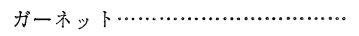 & ……同……... 2/20/51 \\
\hline $2 / 0-100$ & 熔融アルミナお 上び炭化理素…….... & ……同……. 4/16/54 \\
\hline$: 2 / 0-100$ & ガーネット & ……同……... 4/20/50 \\
\hline $0-80$ & 熔融アルミナ & ……同……. $4 / 20 / 50$ \\
\hline $0-80$ & 炭化珪素およびガーネット……….... & ……同 $\cdots \cdots \cdots \cdots \cdot 11$ \\
\hline $1 / 2-($ & $\begin{array}{l}\text { 熔融アルトミナ，炭化珪素およびガー } \\
\text { 拈 }\end{array}$ & . 同 \\
\hline $1-50$ & ルミナ，炭化珪素およびガー & ……同……6 $6 /$ \\
\hline $1 \frac{1}{1 / 2}-40$ & ルミナ, 炭化珪素およびガー & …..同…...... 1 1/ \\
\hline $2-36$ & (n) & 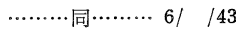 \\
\hline $2-36$ & $F \cdots \cdots \cdots \cdots$ & 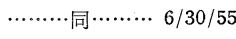 \\
\hline $2 \frac{1}{2}-30$ & $\ldots \ldots \ldots \ldots \ldots \ldots$ & ……同……3 3/ 1/56 \\
\hline $21 / 2-30$ & 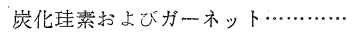 & $\cdots \cdots \cdots \cdots$ 同 $\cdots \cdots \cdots \cdot 10 / 25 / 49$ \\
\hline $3-24$ & 熔峝 & $\cdots \cdots \cdots$ 同 $\cdots \cdots \cdots \cdots, 6 / 24 / 54$ \\
\hline $3-24$ & 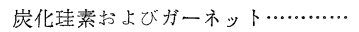 & ……同…… 5/ 9/52 \\
\hline $3{ }^{1 / 2}-20$ & ガーネッ & 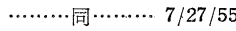 \\
\hline $31 / 2-20$ & 熔融アルミルま & $\cdots \cdots \cdots$ 同 $\cdots \cdots \cdots, \ldots 11 / / 41$ \\
\hline $4-16$ & 熔融 & 熔融アルミナ $\cdots 6 / 11 / 52$ \\
\hline $4-16$ & 炭化珪素. & 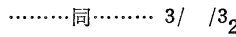 \\
\hline $.4^{1 / 2}-12$ & 熔融アルミナおょび炭化珪素……… & ……同…....11/10/47 \\
\hline 1) & ルミナ, 炭化珪素, ガーネットお & $\begin{array}{l}\text { वे } \\
\text { Y. }\end{array}$ \\
\hline
\end{tabular}

6.1.1.2 エメリ一用：

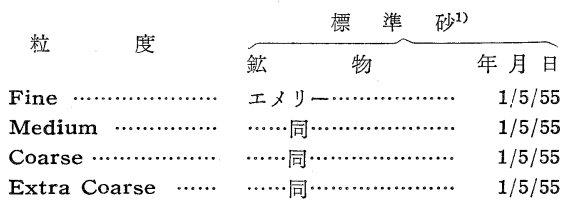

1）熔融アルミナ, 炭化珪素, ガーネットおよびエメリー用として示さ れた標準砂は The Carborundum Co., Niagara Falls, New York から購入できる. 年月日は同定のため当該工業界で現在使用 されている標準砂を示す。

6.1.1.3 フリント (finishing paper) 用:

筆者は光陽研磨材株式会社・技術部

\begin{tabular}{|c|c|c|c|}
\hline & \multirow{2}{*}{ 度 } & \multicolumn{2}{|c|}{ 標 準 砂1) } \\
\hline & & 鉱 & 年月旦 \\
\hline \multirow{2}{*}{\multicolumn{2}{|c|}{ ㄱ... }} & ガーネット.... & $3 / 12 / 52$ \\
\hline & & ……同 & $8 / 5 / 52$ \\
\hline \multicolumn{2}{|c|}{.................. } & …...司 & $12 / 23 / 53$ \\
\hline
\end{tabular}

1） 4/0 フリント (finishing paper) 用標準砂は 6/0-220 熔融アル ミナ，炭敒珪素およびガーネット用標準砂，3/0 用は 5/0-180 熔融 アルミナ用標準砂, 2/0 用は4/0-150熔融アルミナ, 炭化珪素およ びガーネット周標準砂と同じである。これらの標準砂は The Carborundum Co., Niagara Falls, N.Y. から購入厄きる。

6.1.1.4 フリント (paper) 用：

\begin{tabular}{|c|c|c|}
\hline \multirow{2}{*}{ 粒 } & \multicolumn{2}{|c|}{ 標 準 砂 ${ }^{1)}$} \\
\hline & 鉱 & 年月日 \\
\hline Extra Fine. & 石 英…………….... & $4 / 1 / 52$ \\
\hline Fine ............. & …同…………… & $4 / 1 / 52$ \\
\hline Medium ….............. & …同……................ & $4 / 1 / 52$ \\
\hline Coarse & …同ㄱ..….............. & $4 / 1 / 52$ \\
\hline Extra Coarse ....... & …同ㅅ…................ & $4 / 1 / 52$ \\
\hline
\end{tabular}

1) フリント (paper) 用標準砂は Minnesota Mining and Manufacturing Co., 900 Bush Ave., St. Paul 6, Minn. から購入 できる。

6.1.2 標準試験穊一一研磨材粒度測定用の各標準試 験策の諸元は表一4 亿示す．乙れらは絹および金網節か ら成り，研磨材の種類および粒度のおのおのに関しては 表一 5 , 表一6 亿表示する. 標準試験穊は穊分け面積が $12 \mathrm{in}^{2}$ 以上で, 目数と目開きの均一性に関して㛜密に選

\section{表一4 標準試験篩諸元}

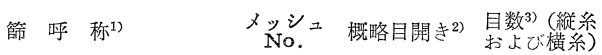

in 1 in 間の目数

21 Std. Dufour............ $178 \quad .0027 \quad 178$

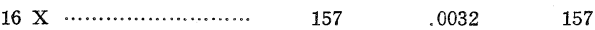

$15 \mathrm{XX}$ Dufour …......... $150 \quad .0036 \quad 150$

13 XX Dufour ….......... $129 \quad .0039 \quad 129$

$11 \mathrm{X}$ Dufour ……......... $116 \quad .0052 \quad 116$

10 X Dufour …............ $109 \quad .0058 \quad 109$

9 Std. Dufour …......... $\quad 97 \quad .0066 \quad 97.5$

$8 \times$ Dufour …............. $\quad 86 \quad .0079 \quad 85.5$

6 Std. Bodmer …..... $\quad 74 \quad .0094 \quad 74$

5 Std. Dufour …......... $66 \quad 66$

3 Std. Dufour ……..... $\quad 58 \quad .0131 \quad 58.5$

1 Std. Dufour …......... $\quad 49 \quad .0164 \quad 48.5$

40 GG Dufour …......... $\quad 39 \quad .0197 \quad 39$

$\begin{array}{llll}38 \text { GG Dufour …......... } \quad 37 & .0215 & 37\end{array}$

32 GG Bodmer............ $32 \quad .0250 \quad 32$

28 GG Dufour …........ $27 \quad .0304 \quad 27.5$

24 GG Bodmer............ $24 \quad .0353 \quad 24$

20 XXXGG Dufour....... $\quad 19 \quad .0456 \quad 19.5$

18 GG Dufour …......... $17 \quad .0519 \quad 17.5$

14 U.S. Std. Wire ….. $14 \quad \begin{array}{llll}.0555 & 12.5\end{array}$

12 U.S. Std. Wire …... $12 \quad .0661 \quad 10.8$

10 U.S. Std. Wire ….. $10 \quad 10 \quad .0787 \quad 9.2$

8 U.S. Std. Wire ….. $\quad 8 \quad .0937 .7 .9$

$\begin{array}{llll}6 & \text { U.S. Std. Wire ….. } & 6 & .1320\end{array}$ 
1）“U.S. Std. Wire” 以外の節は全部縎網から成る。この絹網は Tobler, Ernst and Traber, Inc., New York, N.Y. 加入 手できる. U.S. Std. Wire の穊網は Newark Wire Cloth Co., Newark, N.J. おょび W.S. Tyler Co., Cleveland, Ohio か ら得られる.

2）各絹網の概略目開きは縌糸間を测定した100目の5ちもっとも多く あらわれるモード径または開きを示す。他の方法で測定すれば著し く異なった值を示すであるう。したがってここに示した值を他のも のと比較する場合には充分に注意しなければならない。

3）表記の目数は絹網製造者の標準数であり, 最も近い整数位または $1 / 2$ メッシュ単位に丸めてある. 縦の目数は許容差がさくその標 準数の $\pm 1 \%$ におさえてある.横の目数は幾分大きい許容差をもっ ている.

定し，目開きの寸法や形状をくずさずに網張りしたもの でなければならない。

\subsection{3 試験方法}

6.1.3.1 網粒度の対照規準——網粒度の対照規準の 基礎は一系列の標準砂より成る。てれらは標準試験節の 使用上の適合性を決定するために“標準試験節”を試験

し (6.1.3.2 参照)，かつ製品片から回収した研磨材の 粒度測定值を求め照合するために用いられる（4.1 参 照).

6.1.3.2 標準試験節の選定一一網粒度の粒度測定に 用いられる“標準武験篩”は表一 5 , 表一6亿示す。乙れ らの穊は使用上満足であると考える前に，本項に述べる 方法によって“標準砂”を用いて試験しなければならな い.

ある節をある種類およびある粒度の研磨材に対するコ ントロール節として用いるときは, 当該研磨材の種類お よび粒度に対する“標準砂”を用いてコントロール穊と して武験しなければならない。との穊が表一5, 表一6に 示す限界内のオーバグレイド重量百分率を与えるなら ば，そのかぎりにおいて標準試験節として使用するてと に関し満足であると考える.

同一穊を“トータルグレイドのあらさ”試験に用いた り，同種研磨材のより粗目の粒度または異種研磨材の不 特定の粒度に対するファインズ節として用いる場合に， それがコントロール節として試験して満足すべきもので あるとわかっていればかかる使途付対してその節は満足 であると考えてよい。

特定の穊，すなわち 25 Std., 18 GG および 12 U.S. Std. はファインズ節專用である。乙れらの各篩はその ファインズ穊に該当する研磨材の粒度および種類に対す る標準砂を用いてファインズ穊として試験する．各穊が 表一 5 , 表一6に示す限界内のファインズ重量百分率を与 えるならば，そのかぎりにおいて標準試験穊として使用 するととに関し満足であると考える。

粒度 4-16 および 4 $1 / 2-12$ の“トータルグレイドのあ らさ”試験に用いる 8 U.S. Std. および 6 U.S. Std. 金網穊はかかる使用上の適合性を決定するために標準砂 を用いて試験する必要はない。

6.1.3.3 サンプリング—5.1 に述べた方法で回収
した研磨材の試料と粒度試験に用いられるべき標準砂は つぎに述べるように四分法によって適当な重量に縮分す る.

研磨材を正方形の硬い平らにした紙上に置く、その紙 の対角線上の両かどをつかみ，まずその一方を持ち上げ てから他方を持ち上げ，研磨材を紙の中心より一方のか ぞにてろがしてから反対のかどにてろがし，最後に中心 にもどす.つぎに他の対角線上の両かどをつかんで同様 の方法を繰り返すにてのようにして各方向について少な くとも 5 回ずつ混合をつづけ最後に紙の中心で研磨材を 平らに丸く積み重ねる。

大スパチラを研磨材の山の上から插入して，注意しな がらその山をまず 2 等分しつぎに 4 等分する.ての場 合，スパチラの端が紙面に達するようにして研磨材全部 が分けられるようにする。つぎにスパチラを用いて，必 要があればラクダ毛のブラシを用い，対角位置にある 2 つの $1 / 4$ 部を完全に取り除く.

ての方法を残った研磨材について繰り返す。ただし混 合した後は前回取り除いた部分に対して $90^{\circ}$ の位置にあ る $1 / 4$ 部を取り除くものとする.とのようにして混合し ては交互に $1 / 4$ 部を除く方法を繰り返し，実質上残量が 試験に必要な量になるまでつづける，手で行なう節分け 方法に対する標準試料の重量は 100 グレイン $(6.5 \mathrm{~g})$, 機械による穊分け方法の場合は $10 \mathrm{~g}$ である，最終所要 量にするための微調整はスパチラを用いて行なう.

6.1.3.4 調温調湿一すの゙ての四分化した試料およ び試験装置は試験前 $70^{\circ} \pm 2^{\circ} \mathrm{F}$, 相対湿度 $50 \% \pm 2 \%$ の. 状態に少なくとも 8 時間は保持するとともにすべての試 験が完了するまでこれらの調節された状態を保持しなけ ればならない。

6.1.3.5 手で行なう篩分计方法一粒度測定は $70^{\circ} \pm$ $2^{\circ} \mathrm{F}$, 相対湿度 $50 \% \pm 2 \%$ の調節された状態の下で手で 行なう穊分け方法によって測定する。研磨材はまずファ インズ節を通過させ，つぎにコントロール穊を通過させ て試験する、コントロール穊上に留まった粒子部分はさ らによりあらい篩を介して試験し, 表一1, 表一2 亿示し。 た限界についての適合性を決定する。穊は大体水平に。 保って穊のわくの方を手のひらへ吒くようにして振動さ せる. 振幅は約 1 in とし, 振動数は約 275 回每分とす る、穊分け中は篩のわくをほかの固いもので吒いたりま たは固いものにぶつけてはならない，振動は各節につい.. て篩を通過する研磨材量が每分1 グレインまたはそれ以 下になるまでつづけるものとする。

6.1.3.6 機械による篩分け方法 (別法)—もう1つ。 の試験方法として,つぎの条件で機械式振とう器を用い。 てもよい.

(1) 粒度試験はすべて $70^{\circ} \pm 2^{\circ} \mathrm{F}$ ，相対湿度 $50 \% \pm 二$ $2 \%$ の調節された状態で行なう。 
表一5 熔融了ルミナ, 炭化珪素およびガーネット用標準砂による穊の選定方法および篩分け特性の決定方法 (これらの節後後で回収研磨材の試験用として用いられる)

\begin{tabular}{|c|c|c|c|c|c|c|c|c|c|}
\hline \multirow{2}{*}{ 粒 度 } & \multirow{2}{*}{ 研 磨 材 の 種 類 } & \multirow{2}{*}{$100 \%$ 通過節 } & \multirow[t]{2}{*}{$99.5 \%$ 通過節 } & \multirow{2}{*}{ コントロール節 } & \multicolumn{2}{|c|}{$\begin{array}{l}\text { オーパク゚レイ } \\
⿱ ⺊\end{array}$} & \multirow{2}{*}{ ファインズ篩 } & \multicolumn{2}{|c|}{$\begin{array}{c}\substack{\text { フンズ } \\
(\%)^{2)}} \\
\end{array}$} \\
\hline & & & & & Min. & Max. & & $\overparen{\text { Min. }}$ & Max. \\
\hline $6 / 0-220$ & 熔融アルミナ，炭化珪索およびガーネット….. & $13 \mathrm{XX}$ & $15 \mathrm{XX}$ & 21 Std. & 5.1 & 9.1 & 25 Std. & 45.4 & 65.4 \\
\hline $5 / 0-180$ & 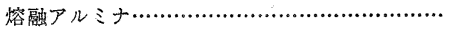 & $11 \mathrm{x}$ & $13 \mathrm{XX}$ & $15 \mathrm{XX}$ & 7.3 & 13.3 & 21 Std. & $\cdots \cdots$ & $\cdots \cdots$ \\
\hline $5 / 0-180$ & 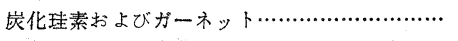 & $11 \mathrm{X}$ & $13 \mathrm{XX}$ & $15 \mathrm{XX}$ & 9.5 & 15.5 & 21 Std. & ….. & $\cdots \cdots$ \\
\hline $4 / 0-150$ & 熔螸アルミナ，炭化珪素およびガーネット….. & 9 Std. & $11 \mathrm{X}$ & $13 \mathrm{xx}$ & 6.7 & 12.7 & $15 \mathrm{XX}$ & $\ldots \ldots$ & ...... \\
\hline $3 / 0-120$ & 熔融アルミナおよび炭化珪素……................... & 6 Std. & 9 Std. & $11 \mathrm{x}$ & 10.9 & 16.9 & $13 \mathrm{xx}$ & $\cdots \cdots$ & $\cdots \cdots$ \\
\hline $3 / 0-120$ & 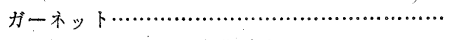 & 6 Std. & 9 Std. & $11 \mathrm{X}$ & 5.5 & 11.5 & $13 \mathrm{xx}$ & $\cdots \cdots$ & $\cdots \cdots$ \\
\hline $2 / 0-100$ & 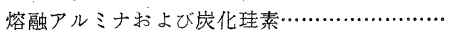 & 3 Std. & 6 Std. & 9 Std. & 3.0 & 6.0 & $11 \mathrm{X}$ & $\cdots \cdots$ & $\cdots \cdots$ \\
\hline $2 / 0-100$ & ガーネット & 3 Std. & 6 Std. & 9 Std. & 6.3 & 12.3 & $11 \mathrm{X}$ & $\ldots \ldots$ & ...... \\
\hline $0-80$ & 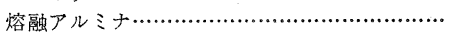 & 1 Std. & 3 Std. & 6 Std. & 8.4 & 14.4 & 9 Std. & $\cdots \cdots$ & $\cdots \cdots$ \\
\hline $0-80$ & 炭化珪素㧍よびガーネット….......................... & 1 Std. & 3 Std. & 6 Std. & 3.0 & 5.3 & 9 Std. & $\cdots \cdots$ & $\cdots \cdots$ \\
\hline $1 / 2-60$ & 熔融アルミナ，炭化拄素およびガーネット….. & $38 \mathrm{GG}$ & 1 Std. & 3 Std. & 4.4 & 8.4 & 6 Std. & $\cdots \cdots$ & ....... \\
\hline $1-50$ & 熔融アルミナ，炭化珪素掞よびガーネット…... & $32 \mathrm{GG}$ & $38 \mathrm{GG}$ & 1 Std. & 3.0 & 6.4 & 3 Std. & $\cdots \cdots$ & $\cdots \cdots$ \\
\hline$-11 / 2-40$ & 熔融アルミナ，炭化珪素およびガーネット…... & $28 \mathrm{GG}$ & $32 \mathrm{GG}$ & $38 \mathrm{GG}$ & 3.0 & 6.0 & 1 Std. & $\cdots \cdots$ & $\cdots \cdots$ \\
\hline $2-36$ & 熔融アルミナ、 & $24 \mathrm{GG}$ & $28 \mathrm{GG}$ & $32 \mathrm{GG}$ & 9.7 & 15.7 & $38 \mathrm{GG}$ & $\cdots \cdots$ & $\cdots \cdots$ \\
\hline $2-36$ & 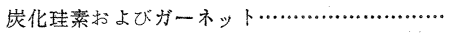 & $24 \mathrm{GG}$ & $28 \mathrm{GG}$ & $32 \mathrm{GG}$ & 5.3 & 9.3 & $38 \mathrm{GG}$ & $\cdots \cdots$ & $\cdots \cdots$ \\
\hline $22^{1 / 2}-30$ & 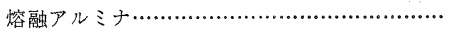 & $20 \times X X G G$ & $24 \mathrm{GG}$ & $28 \mathrm{GG} *$ & 3.0 & 7.0 & $32 \mathrm{GG}$ & $\cdots \cdots$ & $\cdots \cdots$ \\
\hline $21 / 2-30$ & 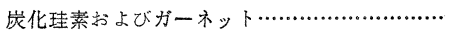 & $20 \times X X G G$ & $24 \mathrm{GG}$ & $28 \mathrm{GG}$ & 14.6 & 20.6 & $32 \mathrm{GG}$ & $\cdots \cdots$ & $\cdots \cdots$ \\
\hline $3-24$ & 熔融アルミナ & 14 US Std. & $20 \mathrm{XXXGG}$ & $24 \mathrm{GG}$ & 8.6 & 14.6 & $28 \mathrm{GG}$ & $\cdots \cdots$ & $\cdots \cdots$ \\
\hline $3-24$ & 炭化珪素およびガーネット……...................... & 14 US Std. & $20 \times \times X G G$ & $24 \mathrm{GG}$ & 8.3 & 14.3 & $28 \mathrm{GG}$ & $\cdots \cdots$ & $\cdots \cdots$ \\
\hline $31 / 2-20$ & 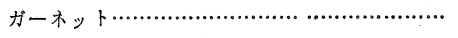 & 10 US Std. & 14 US Std. & $20 \times \times X G G$ & 3.0 & 6.9 & $24 \mathrm{GG}$ & $\cdots \cdots$ & ....... \\
\hline $31 / 2-20$ & 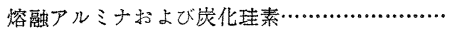 & 10 US Std. & 14 US Std. & $20 \times X X G G$ & 3.7 & 7.7 & $24 \mathrm{GG}$ & $\cdots \cdots$ & $\cdots \cdots$ \\
\hline $4-16$ & 熔融アルミナ & 8 US Std. & 10 US Std. & 14 US Std. & 10.5 & 16.5 & $18 \mathrm{GG}$ & 20.4 & 30.4 \\
\hline $4-16$ & 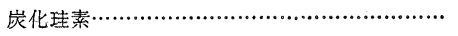 & 8 US Std. & 10 US Std. & 14 US Std. & 9.6 & 15.6 & $18 \mathrm{GG}$ & 15.6 & 25.6 \\
\hline $4 \frac{1 / 2-12}{2}$ & 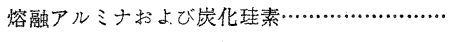 & 6 US Std. & 8 US Std. & 10 US Std. & 7.0 & 13.0 & 12 US Std. & 34.0 & 54.0 \\
\hline $\begin{array}{l}\text { 1) } \\
\text { 2) }\end{array}$ & 㕕昭 & & & & & & & & \\
\hline
\end{tabular}

\section{表一6 エメリーおよびフリント用標準砂による穊の選定方法および篩分け特性の決定方法} (これらの穊は後で回収研磨材の試験用として用いられる)

粒 度 研磨材の種類 $100 \%$ 通過穊 $99.5 \%$ 通過節 コントロール節

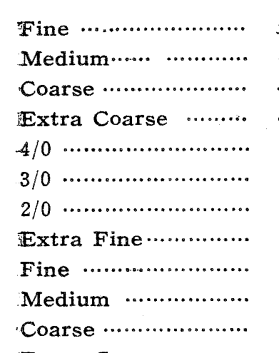

$8 \mathrm{X}$

5 Std.

40 GG

$24 \mathrm{GG}$

$15 \mathrm{XX}$

$13 \mathrm{xX}$

$11 \mathrm{x}$

$10 \mathrm{X}$

5 Std.

$40 \mathrm{GG}$

$28 \mathrm{GG}$

Extra Coarse
…...同…..................... 40 GG

…而……................ $24 \mathrm{GG}$

$20 \times X X G G$
$24 \mathrm{GG}$

1）節に関する詳細は表一4 参照.

2）節がこれらの限界内で標準砂を節分けない場合にはその篩を使用してはならない(6.1.3.2 参照).

（2）標準試験節の検定および粒度測定用に使用する 列磨材の試料は $10 \mathrm{~g}$ とする.

（3）コントロール節は振とう器のファインズ篩の上 住接積み重ね, 試験中試料をコントロール節の上に入 れた場合コントロール篩を通過した部分が直接ファイン ズ節の上に落ちるようにする.

(4) 振とう器の振動数は約 275 回毎分とする.

(5) 試験の長さは 2750 回とする.

（6）篩分け作用は “標準試験篩の選定および限界”

(6.1.3.2 参照) で概説したように，標準試験篩を標準 耖で検定したとき，規定限界内のオーバグレイドおよび ファインズ重量百分率を与えるようなものとする.

(7) オーバグレイド, コントロール, およびファイ
ンズ部分を秤量してから，オーバグレイドをさらに同様

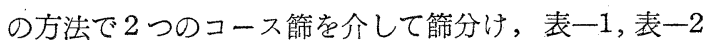
に示した限界についての適合性を決定する。

6.1.3.7 測定值の表示（標準的な粒度測定結果の例） -3/0-120 熔融アルミナ研磨布紙についてその製品片 から研磨材を回収し，ここに述べた方法によって武験し て得た標準的な粒度測定結果をつぎに例示する。

$$
\begin{array}{ll}
3 / 0-120 & \text { 熔融アルミナに対する粒度測定例 } \\
\text { 百 分率 } & \text { 標準砂 試料 限 界 }
\end{array}
$$

6 Std. 老通過した $\% \cdots \cdots \cdots \cdots . . . . . .100 .0$ 実質上 $100 \%$ (痕跡老除く全部)

9 Std. を通過した\%……..... 99.7 最小 99.5

$11 \mathrm{X}$ に留まった\%…… $13.9 \quad 12.0$ 最大 16.7 (標準砂 $\times 6 / 5$ )

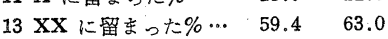

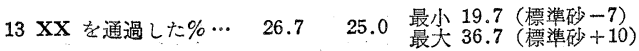


6.1.3.8 審判試験——粒度が論争の問題点となった ときはいつでも問題の研磨材とその標準砂について二重 の試験を行なわなければならない。との場合，標準砂の 試験は問題の研磨材の試験の直前または直後に行なうも のとする・

\section{2 沈降粒度の測定}

6.2.1 沈降法による粒度測定の 理論——研磨材粒子 の大きさまたは粒度の沈降法による測定方法は粘性液中 を落下する小球について適用される Stokes の法則に基 づくもので, 次式で示される.

(1) $V=\frac{2 g r^{2}(p-d)}{9 n}$

$V=$ 落下粒子の沈降速度, $\mathrm{cm} / \mathrm{sec}$

$g=$ 重力加速度, $980 \mathrm{~cm} / \mathrm{sec}^{2} 7$

$r=$ 有効粒子半径, $\mathrm{cm}$

$p=$ 粒子の密度, $\mathrm{g} / \mathrm{cm}^{3}$

$d=$ 沈降媒の密度, $\mathrm{g} / \mathrm{cm}^{3}$

$n=$ 沈降媒の粘度, ポアズ, dyne・sec $/ \mathrm{cm}^{2}$

(1) 式上り

(2) $r(\mathrm{~cm})=\sqrt{\frac{9 n V}{2 g(p-d)}}$

$D=$ 有效粒子直径, $\mu=10,000(2 \mathrm{r})$

$(1 \mathrm{~cm}=10,000 \mu)$

したがって

$$
\begin{aligned}
& D(\mu)=20,000 \sqrt{\frac{9 n V}{2 g(p-d)}} \\
& L=\text { 沈降管の長さ, } \mathrm{cm} \\
& T=\text { 沈降時間, } \mathrm{min} \\
& V \quad(\mathrm{~cm} / \mathrm{sec})=\frac{L}{60 T}
\end{aligned}
$$

$$
D(\mu)=20,000 \sqrt{\frac{9 n L}{2 g(p-d) 60 T}}
$$

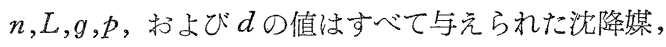
温度，粒子，場所および装置によって一定であるから

$$
20,000 \sqrt{\frac{9 n L}{2 g(p-d) 60}}
$$

を常数 $K$ で置きかえると，(4) 式は次式で示される。

$$
\text { (5) } D(\mu)=K \sqrt{\frac{1}{T}}=\frac{K}{\sqrt{T}}
$$

（5）式を適用する場合には勿論，Kの值を各温度および 各研磨材の種類について計算する必要があるが，てれは $K$ が $L, g$ およびpだけでなく， dおよび $n$ すなわち 沈降媒の密度および粘度にも関係し，ての 2 つがそれぞ れ温度にしたがって変化するからである。

沈降法によって粒子の大きさを測定するために，研磨 布紙に通常用いられている研磨材は一般につぎに示すよ うな密度を有するものと見做す。

7 重力加速度 $g$ の值は標高および緯度に関係する. 国際度量 衡委員会は承認値として $980.665 \mathrm{~cm} / \mathrm{sec}^{2}$ という数值を採択し ているが，980 といら值を充分正確なものとして使用してよい。

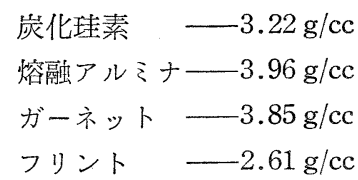

6.2.2 標準沈降装置 8 一沈降粒度の粒度測定に用い られる沈降装置はつぎに示す要素から成り, 図一～亿示 すように組立てられたものでなければならない。

（1）ガラス製ウォータージャケット：長さ $87 \sim 90$ $\mathrm{cm}$, 直径 $6 \sim 9 \mathrm{~cm}$.

（2）沈降管 (sedimentation tube)：長さ $94 \mathrm{~cm}$, 内 径 $20 \mathrm{~mm} \pm 1 / 2 \mathrm{~mm}$. この管は完全に円筒形でなければ ならない。

（3）特殊設計の収集管 (collecting tube) ${ }^{9}$ : あらゆ る点で図一 3 亿示すものと等しいもの，その管端は側壁 と直角であり，刻み目盛は正確なものでなければならな い.

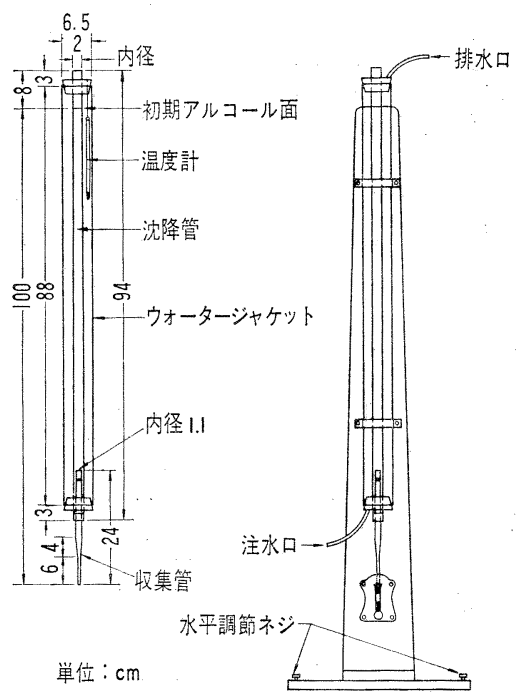

四一3 標準沈降装置の組立図

(4) $0^{\circ} \sim 100^{\circ} \mathrm{C}$ 目盛, 精度 $\pm 0.2^{\circ} \mathrm{C}$ の温度計.

(5) 1/100 min まで読みとれるストップウオッチま たは正確な電気時計.

（6）ガラス製ウォータージャケット，沈降管および 収集管を保持するために必要なりングおよび取付具を具 備したフレーム。

（7）装置に安定性をもたせるために充分な大きさと 重さを有する 1 in の金属製基板：フレームを取付ける 穴があけられてあり，垂直位置任組立調節ができる調節 ネジを有するもの.

（8）つぎの付属品

8 標準沈降装置および標準沈降媒は Minnesota Mining and Manufacturing Co., 900 Bush Ave., St. Paul 6, Minn. か ら入手できる.

9 Fischer Scientific Co., 717 Forbes Street, Pittsburgh. 19, Pa. から入手できる. 

(a) 試験管
(e) 拡大鏡
(b) 洗浄瓶
(f) 継ざ目無し漏斗
(c) 錘
( $\mathrm{g}$ ) 物指
(d) ゴムストッパー
(h) ゴムポリスマン

6.2.3 標準沈降媒 ${ }^{10}$ —沈降媒は $95 \%$ メチルアルコ ールと 99\% メチルアルコール（合成メタノール）の混 合液から成るもので, 後述する方法により検定用試料に 対して本規格に表記するル值を与えるよう注意して配合 されたものでなければならない。

6.2.4 同定一一本規格において適用される研磨布紙 の沈降粒度と, 図一- 図一2 に示したそれらの標準粒度 累積曲線の同定はつぎによる。

\subsubsection{1 而水研磨布紙用：}

\begin{tabular}{|c|c|c|}
\hline 粒度 & 物 & 標 準曲 線1) \\
\hline 600 & 熔融アルミナおょび炭化理萃. & 600 , 年月日 $9 / 12 / 35$ \\
\hline 500 & 熔融アルミナおよび炭化珪素... & 500 , 年月日 $3 / 18 / 37$ \\
\hline 400 & 熔融アルミナおよび炭化珪素............. & 400 , 年月日 $2 / 6 / 36$ \\
\hline 360 & 熔融アルミナおよび炭化珪素.............. & 360 , 年月日 $9 / 13 / 33$ \\
\hline 320 & 熔融アルミナおよび炭化珪素…. & 320 , 年月日 $9 / 13 / 33$ \\
\hline 280 & 熔融アルミナおよひび炭化珪素….......... & 280 , 年月日 $9 / 13 / 33$ \\
\hline 240 & 熔融アルミナおよび炭化珪素…............ & 240 , 年月日 $9 / 13 / 33$ \\
\hline $8 / 0$ & ガーネット…....... & 280 , 年月日 $3 / 17 / 37$ \\
\hline $7 / 0$ & ガーネッ & 240 , 年月日 $3 / 17 / 37$ \\
\hline 1) & 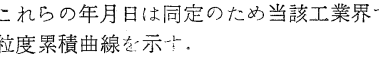 & \\
\hline
\end{tabular}

\subsubsection{2 耐水以外の研祭布紙用：}

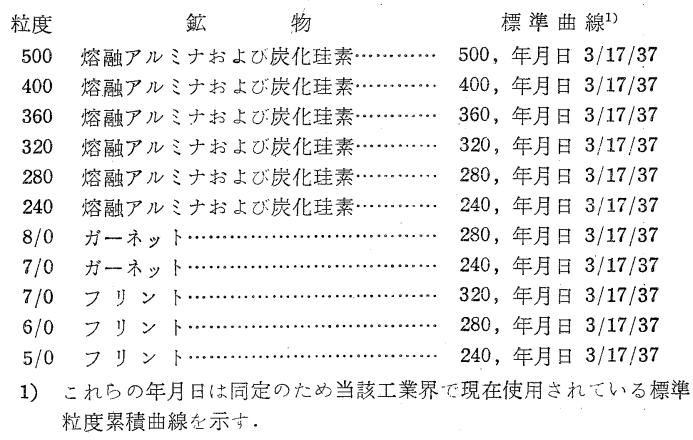

6.2.4.3 検定用試料の曲線一標準検定用試料の $\mu$ 值は図一 4 亿示す.

\subsection{5 試験方法}

6.2.5.1 沈降粒度の対照規準一一沈降粒度の対照規 準の基礎は，図一4 亿示す“標準検定用試料”11 の一組 の曲線と, 図一1, 図一 2 亿示した“標準曲線”と呼ばれ る一系列の標準粒度累積曲線とから成る。検定用試料は 沈降装置を補正するためおよび沈降媒ならびに試験方法 を検定するために用いられる。標準曲線は沈降粒度に対 する粒度限界の適合性を決定するための照合に用いられ る.

\footnotetext{
10 脚注 8 参照.

111 組の標準検定用試料は Minnesota Mining and Manufacturing Co., 900 Bush Ave., St. Paul 6, Minn. 加 入 手できる。これらの検定用試料は沈降粒度の調製について概説 した方法に従って処理してあるから，良い湿潤性を保証するた めにさらに処理する必要はない。
}

沈降粒度の粒度測定は, “装置の補正”（6.2.5.2）で 述べるように，組立てられた沈降装置，沈降媒，および 試験方法が検定補正され，得られた 值が 6.2.5.2 亿規 定する限界内で図一 4 亿表示するそれと一致してから測 定しその標準曲線と照合しなければならない。

6.2.5.2 装置の補正一一沈降装置を組立てたら, 結 果の精度を容易に害するような重要な変量について検定 しなければならないままず，紐糸に鍾をつけて十字線に かけ，沈降管の上端から糸か汉集管を通過して垂れ下が るようにして組立てた装置の垂直性を検定する。もし糸 が沈降管と収集管の中心を通過しなければ，ての条件が 満たされるまで基板の水平調節ネジによって装置の垂直 性を調節する。

収集管は沈積柱の中心を通るように配置し，その管の 上端から約 $3 \mathrm{~cm}$ のところに位置せしめたゴム座金でし っかり保持し，収集管の下にあるゴムストッパーを軽く 吒いた場合に沈降媒中で洞流が生じないようにする。沈 降管は沈降媒の液柱長さが正確に $100 \mathrm{~cm}$ になるよう組 立てるものとする.

ての装置が上述のように検定されて正しく組立てられ てから，検定用試料の1つまたはそれ以上の試験管試料 を粒度測定して試験の総合精度を測定する。総合精度は $10,20,30,40$ および $50 \mathrm{H} \%$ 点の $\mu$ 值について測定す る.てれら各点の值は, その検定用陚料を試験して得た 累積曲線から読みとるのであるが， $\pm 0.5 \mu$ の範围で図 -4 亿表示する值と一致し, かつその偏差の代数和平均 が $\pm 0.3 \mu$ をてえてはならない。もしての両条件か満た されるならば試験のすべての要素はその状態でよいもの とし, 沈降粒度の粒度測定を実施してその標準曲線と照 合してよいものと考える。もしてれらの条件の一方また は両方が満たされなければ，装置が正しく調節されてい ないか, 試験を行なう方法か䛠っているか，または沈降 媒の密度および（または）粘度が適正でないと考光る。 乙の場合, 装置を再検定して調節し, 試験方法を詳細に 調べ，さらに新しいロットの沈降媒および検定用試料を

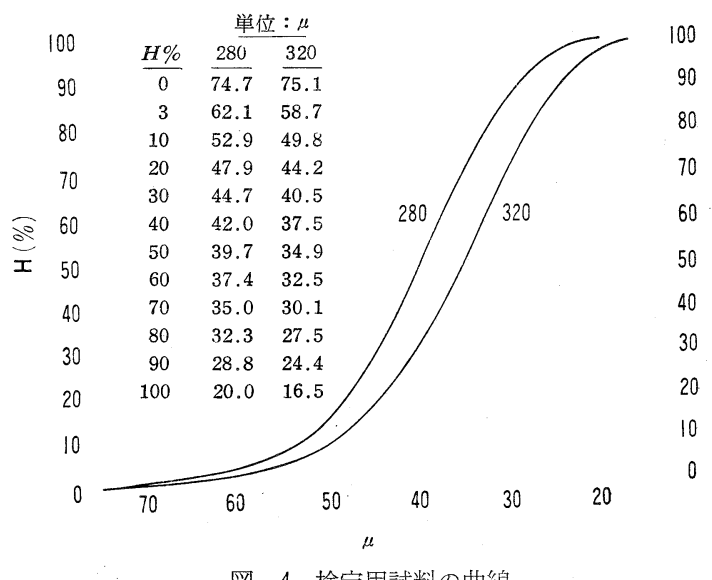

図一4 検定用試料の曲線 
用いて試験し, 不正確な結果の原因をつきとめて補正し なければならない。

6.2.5.3 粒度測定の方法と粒度分析一一粒度分析は つぎのように数段階に分けて行なう。

（1）粒度測定を行なう試料をローリング (rolling) または四分法によって充分に混合する。つぎに沈降した 場合に収集管中で 20 乃至 25 目盛分が充分に保証できる ような量の試料を試験管に入れる.沈降媒 $15 \mathrm{ml}$ を加え て標準のゴムポリスマンで試験管中の試料を静かに擋拌 し，親指で軽く管の開口部をおさえながら試験管を振と うしはやく回転してから水平にもどして，管の底に少し も団塊が認められなくなるまでてれをつづける。との試 料抢よび沈降媒は陚験管に入れたまま少なくとも $1 / 2$ 時 間, なるべくなら 1 時間放置し, ての間 3 回激しく振と うする．浸漬時間中，武験管内の沈降媒の温度は沈降管 内の沈降媒と同温度に保持しなければならない。

（2）沈降管に沈降媒を入れて収集管の底から 100 $\mathrm{cm}$ の点まで満たし, その温度が沈降管周壁のウォータ 一ジャケットの水温と平衡になるまで放置する。沈降管 の温度, ウォータージャケットの水温および武験管中の 沈降媒の温度を調べ，すべて同温で $20 \sim 30^{\circ} \mathrm{C}$ の範囲内 になるよう保持する。

（3）適当な漏斗を沈降管上に置く，試料および沈降 媒が入っている試験管の開口部を親指で軽くおさえ，少 なくとも 30 秒激しく振とうする．試験管の開口部を漏 斗上で転倒して内容物をすみやかに沈降管中に移し, 試 料が流出するとき試料が漏斗の斜面を流れて沈降媒の液 面に流れ落ちるようにする。

（4）乙の移す時間を沈降開始時間として記録する. すみやかに沈降管の上の漏斗を取り去り，試料が少しで も沈降開始後に管中に滴下するのを避ける。乙れは結果 を悪くするからである．

（5）起点時間は研磨材粒子の規則的な最初の流れが 収集管の底に到達した時間として考える，その落下する 粒子を調べて調製方法が適当に行なわれていたかどうか を決めなければならない，団塊や灰片があれば試料の調 製が適当でないか不充分であるととを示す．かかる状態 が存在したら，その分析は棄却しなければならない。

(6) 研磨材の高さが刻み目盛をちょうど通過して上 昇しかける点をとる。粒度測定の終点は研磨材粒子が全 部沈降したときすなわち研磨材柱が動かず上昇しなく なったときの時間として考光る。

（7）研磨材粒子が下降している間，粒子を詰めその 水平面を保つために収集管の底にあるゴムストッパーを しずか絶えず吒き，正確な読みが得られるようにす る.との吒きには 1 in のゴム吸引管を一端にはめた鉛 筆を用いる。吒く部分は収集管の下側のゴムストッパー の前面 $1 / 4$ 部分とする．沈降管を支持している金属ア一
ムや収集管自体を吒いてはならない。

6.2.5.4 測定值の表示一沈降法により測定された 粒度測定結果 を 表示するには “H\% 表”, 表一3，およ び 1 組の “時間一直径表”, 表一7〜表一10 を用いる。 $H \%$ 表は 20.0 25.0 目盛間の全沈降点に対し各沈降 点について表わした累積高さ $\%(H \%)$ を示す. 時間一 直径表は沈降媒が $25^{\circ} \mathrm{C}$ の場合の異なった沈降時間に対 する種々の粒子の有効直径を $\mu$ で示す.

種々の沈降時間を測定したのち, H\% 表および適当な 時間一直径表汃ら各沈降点について表わされた $H \%$ お よび にH\% をとって累積曲線をプロットする. 同じグラフ に同じ方法で，試験した研磨布紙に対する標準曲線を $3 \%$ 点から $50 \%$ 点までについてプロットする.

沈降媒の温度が $25^{\circ} \mathrm{C}$ 以外の場合の沈降時間一直径表

表一7 熔融厂ルミナ用 沈降時間一直径值, $25^{\circ} \mathrm{C}$

\begin{tabular}{|c|c|c|c|c|c|c|c|}
\hline $\begin{array}{c}\text { 時間 } \\
(\mathrm{min})\end{array}$ & $\begin{array}{r}\text { 直径 } \\
(\mu)\end{array}$ & $\begin{array}{c}\text { 時間 } \\
(\mathrm{min})\end{array}$ & $\begin{array}{r}\text { 植径 } \\
(\mu)\end{array}$ & $\begin{array}{c}\text { 時間 } \\
(\mathrm{min})\end{array}$ & $\begin{array}{r}\text { 直径 } \\
(\mu)\end{array}$ & $\begin{array}{c}\text { 時間 } \\
(\mathrm{min})\end{array}$ & $\begin{array}{r}\text { 直径 } \\
(\mu)\end{array}$ \\
\hline .50 & 112.71 & 2.75 & 48.06 & 5.00 & 35.64 & 11.00 & 24.03 \\
\hline .55 & 107.47 & .80 & 47.63 & .10 & 35.29 & .20 & 23.81 \\
\hline .60 & 102.89 & .85 & 47.21 & .20 & 34.95 & .40 & 23.60 \\
\hline .65 & 98.86 & .90 & 46.80 & .30 & 34.62 & .60 & 23.40 \\
\hline .70 & 95.27 & .95 & 46.40 & .40 & 34.29 & .80 & 23.20 \\
\hline .75 & 92.03 & 3.00 & 46.01 & .50 & 33.98 & 12.00 & 23.01 \\
\hline .80 & 89.11 & .05 & 45.63 & .60 & 33.67 & .50 & 22.54 \\
\hline .85 & 86.45 & .10 & 45.26 & .70 & 33.38 & 13.00 & 22.10 \\
\hline .90 & 84.01 & .15 & 44.90 & .80 & 33.09 & .50 & 21.59 \\
\hline .95 & 81.78 & .20 & 44.55 & .90 & 32.81 & 14.00 & 21.30 \\
\hline 1.00 & 79.70 & .25 & 44.21 & 6.00 & 32.54 & .50 & 20.93 \\
\hline .05 & 77.78 & .30 & 43.87 & .10 & 32.26 & 15.00 & 20.57 \\
\hline .10 & 75.99 & .35 & 43.54 & .20 & 32.00 & .50 & 20.24 \\
\hline .15 & 74.33 & .40 & 43.22 & .30 & 31.75 & 16.00 & 19.92 \\
\hline .20 & 72.76 & .45 & 42.90 & .40 & 31.50 & .50 & 19.62 \\
\hline .25 & 71.29 & 3.50 & 42.60 & .50 & 31.26 & 17.00 & 19.33 \\
\hline .30 & 69.91 & .55 & 42.30 & .60 & 31.02 & .50 & 19.05 \\
\hline .35 & 68.59 & .60 & 42.00 & .70 & 30.79 & 18.00 & 18.78 \\
\hline .40 & 67.36 & .65 & 41.71 & .80 & 30.56 & .50 & 18.53 \\
\hline .45 & 66.19 & .70 & 41.43 & .90 & 30.34 & 19.00 & 18.28 \\
\hline .50 & 65.07 & .75 & 41.15 & 7.00 & 30.13 & .50 & 18.04 \\
\hline .55 & 64.02 & .80 & 40.88 & .10 & 29.91 & 20.00 & 17.82 \\
\hline .30 & 63.00 & .85 & 40.61 & .20 & 29.70 & .50 & 17.60 \\
\hline .65 & 62.04 & .90 & 40.35 & .30 & 29.49 & 21.00 & 17.39 \\
\hline .70 & 61.12 & .95 & 40.10 & .40 & & 22.00 & 16.99 \\
\hline .75 & 60.25 & 4.00 & 39.85 & .50 & 29.10 & 23.00 & 16. 31 \\
\hline .80 & 59.40 & .05 & 39.60 & .60 & 28.91 & 24.00 & 16.26 \\
\hline .85 & 59.59 & .10 & 39.36 & .70 & 28.72 & 25.00 & 15.94 \\
\hline .90 & 57.82 & .15 & 39.12 & .80 & 28.53 & 26.00 & 15.63 \\
\hline .95 & 57.07 & .20 & 38.89 & .90 & 28.35 & 27.00 & 15.33 \\
\hline 2.00 & 56.35 & .25 & 38.66 & 8.00 & 28.18 & 28.00 & 15.06 \\
\hline .05 & 55.66 & .30 & 38.43 & .20 & 27.83 & 29.00 & 14.80 \\
\hline .10 & 54.99 & .35 & 38.21 & .40 & 27.49 & 30.00 & 14.55 \\
\hline .15 & 54.35 & .40 & 37.99 & .60 & 27.17 & 32.00 & 14.08 \\
\hline .20 & 53.73 & .45 & 37.78 & .80 & 26.86 & 34.00 & 13.66 \\
\hline .25 & 53.13 & .50 & 37.57 & 9.00 & 26.56 & 36.00 & 13.28 \\
\hline .30 & 52.55 & .55 & 37.36 & .20 & 26.27 & 38.00 & 12.93 \\
\hline .35 & 51.99 & .60 & 37.16 & .40 & 25.99 & 40.00 & 12.60 \\
\hline .40 & 51.44 & .65 & 36.96 & .60 & 25.72 & 42.00 & 12.29 \\
\hline .45 & 50.92 & .70 & 36.76 & .80 & 25.46 & 44.00 & 12.01 \\
\hline .50 & 50.40 & .75 & 36.57 & 10.00 & 25.20 & 46.00 & 11.75 \\
\hline .55 & 49.91 & .80 & 36.37 & .20 & 24.96 & 48.00 & 11.50 \\
\hline .60 & 49.42 & .85 & 36.19 & .40 & 24.71 & 50.00 & 11.27 \\
\hline .65 & 48.96 & .90 & 36.00 & .60 & 24.48 & 55.00 & 10.84 \\
\hline .70 & 48.50 & .95 & 35.82 & .80 & 24.25 & 60.00 & 10.29 \\
\hline
\end{tabular}


表一8 炭化珪素用 沈降時間一直径值, $25^{\circ} \mathrm{C}$

\begin{tabular}{|c|c|c|c|c|c|c|c|}
\hline $\begin{array}{l}\text { 時間 } \\
(\mathrm{min})\end{array}$ & $\begin{array}{r}\text { 直径 } \\
(\mu)\end{array}$ & $\begin{array}{c}\text { 時間 } \\
(\mathrm{min})\end{array}$ & $\begin{array}{r}\text { 直径 } \\
(\mu)\end{array}$ & $\begin{array}{c}\text { 時間 } \\
(\mathrm{min})\end{array}$ & $\begin{array}{r}\text { 直径 } \\
(\mu)\end{array}$ & $\begin{array}{c}\text { 時間 } \\
(\mathrm{min})\end{array}$ & $\begin{array}{r}\text { 直径 } \\
(\mu)\end{array}$ \\
\hline .50 & 128.8 & 2.75 & 54.93 & 5.00 & 40.74 & 11.00 & 27. \\
\hline .55 & 122.8 & .80 & 54.44 & .10 & 40.34 & .20 & 27. \\
\hline .60 & 117.6 & .85 & 53.96 & .20 & 39.95 & .40 & 26.5 \\
\hline .65 & 112.9 & .90 & 53.49 & .30 & 39.57 & .60 & 26.7 \\
\hline .70 & 108.8 & .95 & 53.04 & .40 & 39.20 & .80 & 6.5 \\
\hline .75 & 105.1 & 3.00 & 52.59 & 5.50 & 38.84 & 12.00 & 6. \\
\hline .80 & 101.8 & .05 & 52.16 & .50 & 38.49 & .50 & 5.7 \\
\hline .85 & 98.8 & .10 & 51.74 & .70 & 38.15 . & 13.00 & 5.27 \\
\hline .90 & 96.0 & .15 & 51.32 & .80 & 37.82 & .50 & 24.7 \\
\hline .95 & 93.4 & .20 & 50.93 & .90 & 37.50 & 14.00 & 24.3 \\
\hline 1.00 & 91.10 & 3.25 & 50.53 & 6.00 & 37.19 & .50 & 23.9 \\
\hline .05 & 88.91 & .30 & 50.15 & .10 & 36.88 & 15.00 & 23. \\
\hline .10 & 86.92 & .35 & 49.77 & .20 & 36.58 & .50 & 23.1 \\
\hline .15 & 84.95 & .40 & 49.40 & .30 & 36.29 & 16.00 & 22.7 \\
\hline .20 & 83.16 & .45 & 49.04 & .40 & 36.01 & .50 & 22.4 \\
\hline 1.25 & 81.48 & 3.50 & 48.69 & 6.50 & 35.73 & 17.00 & 22.0 \\
\hline .30 & 79.91 & .55 & 48.35 & .60 & 35.46 & .50 & 21.7 \\
\hline .35 & 78.41 & .60 & 48.01 & .70 & 35.19 & 18.00 & 21.4 \\
\hline .40 & 76.99 & .65 & .68 & .80 & 34.93 & .50 & 21.1 \\
\hline .45 & 75.65 & .70 & 7.36 & .90 & 34.68 & 19.00 & 20.9 \\
\hline 1.50 & 74.38 & 3.75 & 47.04 & 7.00 & 34.43 & .50 & 20.6 \\
\hline .55 & 73.17 & .80 & $4 \hat{6} .73$ & .10 & 34.19 & 20.00 & 20.3 \\
\hline .60 & 72.02 & .85 & 46.42 & .20 & 33.95 & .50 & 20.1 \\
\hline .65 & 70.92 & .90 & 46.13 & .30 & 33.71 & 21.00 & 19.8 \\
\hline .70 & 69.87 & .95 & 45.83 & .40 & 3.49 & 2.00 & .4 \\
\hline 1.75 & 68 & 4.00 & .55 & 7.50 & 33.26 & 3.00 & 18.9 \\
\hline .80 & 67 &.$(5$ & 45.26 & .60 & 3.04 & 24.10 & 18.5 \\
\hline .85 & 66.98 & .10 & 44.99 & .70 & 32.83 & 25.00 & 18.2 \\
\hline .90 & 66.09 & .15 & 44.72 & .80 & 32.51 & 26.00 & 17.8 \\
\hline .95 & 65.23 & .20 & 44.45 & .90 & 2.41 & 27.00 & 17.5 \\
\hline 2.00 & 64.41 & 4.25 & 44.19 & 8.00 & 32.20 & 8.00 & 17.2 \\
\hline .05 & 63.63 & .30 & 43.93 & .20 & 31.81 & 9.00 & 16.9 \\
\hline .10 & 62.86 & .35 & 43.63 & .40 & 31.43 & 0.00 & 16.6 \\
\hline .15 & 62.13 & .40 & 43.43 & .60 & 31.06 & 2.00 & 16.1 \\
\hline .20 & 61.42 & .45 & 43.18 & .80 & 30.71 & 4.00 & 15.6 \\
\hline 2.25 & 60 & 4.50 & 42.94 & 9.00 & 30.36 & 6.00 & 15.1 \\
\hline .30 & 60.07 & .55 & 42.70 & .20 & 30.03 & 8.60 & 14.7 \\
\hline .35 & 59.42 & .60 & 42.47 . & .40 & 29.71 & 0.00 & 14.4 \\
\hline .40 & 58.80 & .65 & .24 & .60 & 29.40 & 2.00 & 14.0 \\
\hline .45 & 58.20 & .70 & 42.02 & .80 & 29.10 & 4.00 & 13.7 \\
\hline 2.50 & 57.61 & 4.75 & 41.80 & 10.00 & 28.80 & 6.00 & 13.4 \\
\hline .55 & 57.05 & .80 & 41.58 & .20 & 28.52 & 8.00 & 13. \\
\hline .60 & 56.49 & .85 & 41.36 & .40 & 28.24 & 0.00 & 12 \\
\hline .65 & 55. & .90 & 41.15 & .60 & 27.98 & 55.00 & \\
\hline .70 & 55.44 & .95 & 40.94 & .80 & 27.72 & 60.00 & 11. \\
\hline
\end{tabular}

表一9 ガーネット用 沈降時間一直径值, $25^{\circ} \mathrm{C}$

時間 直径|時間 直径|時間 直径|時間 直径

$(\min ) \quad(\mu) \quad(\min ) \quad(\mu) .(\min ) \quad(\mu) . \quad(\min ) \quad(\mu)$

\begin{tabular}{ll|ll|ll|ll}
0.50 & 114.69 & 1.40 & 68.54 & 2.30 & 53.47 & 3.20 & 45.33
\end{tabular}

\begin{tabular}{ll|lll|lll|ll}
.55 & 109.35 & .45 & 67.35 & .35 & 52.90 & .25 & 44.98
\end{tabular}

\begin{tabular}{ll|ll|ll|ll}
.60 & 104.71 & .50 & 66.22 & .40 & 52.35 & .30 & 44.64
\end{tabular}

\begin{tabular}{ll|ll|ll|ll}
.65 & 100.59 & .55 & 65.14 & .45 & 51.81 & .35 & 44.30
\end{tabular}

\begin{tabular}{ll|ll|ll|ll}
.70 & 96.93 & .60 & 64.11 & .50 & 51.29 & .40 & 43.98
\end{tabular}

\begin{tabular}{ll|ll|ll|ll}
.75 & 93.64 & .65 & 63.13 & .55 & 50.78 & .45 & 43.66
\end{tabular}

\begin{tabular}{ll|ll|ll|ll}
.80 & 90.67 & .70 & 62.20 & .60 & 50.29 & 3.50 & 43.35
\end{tabular}

\begin{tabular}{ll|ll|ll|ll}
.85 & 87.97 & .75 & 51.30 & .65 & 49.82 & .55 & 43.04
\end{tabular}

\begin{tabular}{ll|ll|ll|ll}
.90 & 85.49 & .80 & 60.45 & .70 & 49.35 & .60 & 42.74
\end{tabular}

\begin{tabular}{ll|ll|ll|ll|}
.95 & 83.21 & .85 & 59.62 & .75 & 48.90 & .65 & 42.45
\end{tabular}

\begin{tabular}{ll|ll|ll|ll|}
1.00 & 81.10 & .90 & 58.83 & .80 & 48.46 & .70 & 42.16
\end{tabular}

\begin{tabular}{ll|ll|ll|ll}
.05 & 79.15 & .95 & 58.07 & .85 & 48.04 & .75 & 41.88
\end{tabular}

\begin{tabular}{ll|ll|ll|ll}
.10 & 77.32 & 2.00 & 57.34 & .90 & 47.52 & .80 & 41.60
\end{tabular}

\begin{tabular}{rr|rr|rr|rr}
.15 & 75.63 & .05 & 53.64 & .95 & 47.21 & .85 & 41.33
\end{tabular}

\begin{tabular}{ll|ll|ll|ll}
.20 & 74.03 & .10 & 55.96 & 3.00 & 46.82 & .90 & 41.06
\end{tabular}

\begin{tabular}{ll|ll|ll|ll}
.25 & 72.54 & .15 & 55.31 & .05 & 46.43 & .95 & 40.80
\end{tabular}

\begin{tabular}{ll|ll|ll|ll}
.30 & 71.13 & .20 & 54.67 & .10 & 46.06 & 4.00 & 40.55
\end{tabular}

\begin{tabular}{ll|ll|ll|ll}
.35 & 69.80 & .25 & 54.06 & .15 & 45.69 & .05 & 40.30
\end{tabular}

\begin{tabular}{|c|c|c|c|c|c|c|c|}
\hline $\begin{array}{l}\text { 特間 } \\
\text { min) }\end{array}$ & $\begin{array}{r}\text { 直径 } \\
(\mu)\end{array}$ & $\begin{array}{c}\text { 時間 } \\
(\mathrm{min})\end{array}$ & $\begin{array}{c}\text { 直径 } \\
(\mu)\end{array}$ & $\begin{array}{c}\text { 時間 } \\
(\mathrm{min})\end{array}$ & $\begin{array}{r}\text { 直径 } \\
(\mu)\end{array}$ & $\begin{array}{l}\text { 時間 } \\
(\mathrm{min})\end{array}$ & $\begin{array}{r}\text { 直徍 } \\
(\mu)\end{array}$ \\
\hline 4.10 & 40.05 & 5.90 & 33.38 & 9.20 & 25.73 & 18.50 & 18.85 \\
\hline . 15 & 39.81 & 6.00 & 33.11 & .40 & 26.45 & 19.00 & 18.60 \\
\hline .20 & 39.57 & .10 & 32.83 & .50 & 26.17 & .50 & 18.36 \\
\hline .25 & 39.34 & .20 & 32.57 & .80 & 25.90 & 20.00 & 18.1 \\
\hline .30 & 39.11 & .30 & 32.31 & 10.00 & 25.64 & .50 & 17.91 \\
\hline .35 & 38.88 & .40 & 32.05 & .20 & 25.39 & 21.00 & 17.6 \\
\hline .40 & 38.66 & .50 & 31.81 & .40 & 25.14 & 22.00 & 17.2 \\
\hline .45 & 38.44 & .60 & 31.56 & .60 & 24.91 & 23.00 & 16.9 \\
\hline .50 & 38.23 & .70 & 31.33 & .80 & 24.67 & 24.00 & 16.5 \\
\hline .55 & 38.02 & .80 & 31.10 & 11.00 & 24.45 & 25.00 & 16.2 \\
\hline .60 & 37.81 & .90 & 30.87 & .20 & 24.23 & 26.00 & 15.90 \\
\hline .65 & 37.61 & 7.00 & 30.65 & .40 & 24.02 & 27.00 & 15.6 \\
\hline .70 & 37.40 & 10 & 30.43 & .60 & 23.81 & 28.00 & 15.3 \\
\hline .75 & 37.21 & .20 & 30.22 & .80 & 23.60 & 29.00 & 15.0 \\
\hline .80 & 37.01 & .30 & 30.01 & 12.00 & 23.41 & 30.00 & 14.80 \\
\hline .85 & 36.82 & .40 & 29.81 & .50 & 22.93 & 32.00 & 14.33 \\
\hline .90 & 36.63 & .50 & 29.61 & 13.00 & 22.49 & 34.00 & 13.90 \\
\hline .95 & 36.45 & .60 & 29.41 & .50 & 22.07 & 36.00 & 13.51 \\
\hline 5.00 & 36.27 & .70 & 29.22 & 14.00 & 21.67 & 38.00 & 13.15 \\
\hline .10 & 35.91 & .80 & 29.03 & .50 & 21.29 & 40.00 & 12.8 \\
\hline .20 & 35.56 & .90 & 28.85 & 15.00 & 20.94 & 42.00 & 12.51 \\
\hline .30 & 35.22 & 8.00 & 28.67 & .50 & 20.59 & 44.00 & 12.2 \\
\hline .40 & 34.90 & .20 & 28.32 & 16.00 & 20.27 & 48.00 & 11.70 \\
\hline .50 & 34.58 & .40 & 27.98 & .50 & 19.96 & 50.00 & 11.48 \\
\hline .60 & 34.27 & .60 & 27.65 & 17.00 & 19.66 & 55.00 & 10.5 \\
\hline .70 & 3.97 & .80 & 27.33 & .50 & 19.38 & 60.00 & 10.4 \\
\hline .80 & 33.67 & 9.00 & 27.03 & 18.00 & 19.11 & & \\
\hline
\end{tabular}

表一10 フリント用 沈降時間一直径值, $25^{\circ} \mathrm{C}$

時間 直径|時間 直径|時間 直径|時間, 直径

\begin{tabular}{ll|ll|llll}
$(\min )$ & $(\mu)$ & $(\min )$ & $(\mu)$ & $(\min )$ & $(\mu)$ & $(\min )$ & $(\mu)$
\end{tabular}

\begin{tabular}{ll|ll|ll|ll|}
0.50 & 148.9 & 2.35 & 68.69 & 4.20 & 51.38 & 6.05 & 42.81
\end{tabular}

\begin{tabular}{ll|ll|ll|l|l}
.55 & 141.9 & .40 & 67.97 & .25 & 51.07 & .10 & 42.63
\end{tabular}

\begin{tabular}{ll|ll|ll|ll|}
.60 & 135.9 & .45 & 67.27 & .30 & 50.78 & .20 & 42.29
\end{tabular}

\begin{tabular}{ll|ll|ll|ll}
.65 & 130.6 & .50 & 66.59 & .35 & 50.48 & .30 & 41.95
\end{tabular}

\begin{tabular}{ll|ll|ll|ll}
.70 & 125.8 & .55 & 65.94 & .40 & 50.20 & .40 & 41.62
\end{tabular}

\begin{tabular}{ll|ll|ll|ll}
.75 & 121.5 & .60 & 65.30 & .45 & 49.91 & .50 & 41.30
\end{tabular}

\begin{tabular}{ll|ll|ll|ll}
.80 & 117.7 & .65 & 64.68 & .50 & 49.63 & .60 & 40.98
\end{tabular}

\begin{tabular}{ll|ll|l|l|l|l|l}
.85 & 114.2 & .70 & 64.08 & .55 & 49.36 & .70 & 40.38
\end{tabular}

\begin{tabular}{ll|ll|ll|ll}
.90 & 111.0 & .75 & 63.49 & .60 & 49.09 & .80 & 40.38
\end{tabular}

\begin{tabular}{ll|ll|ll|ll}
.95 & 108.0 & .80 & 62.92 & .65 & 48.83 & .90 & 40.08
\end{tabular}

\begin{tabular}{ll|ll|l|l|l|l|}
1.00 & 105.3 & .85 & 62.37 & .70 & 48.57 & 7.00 & 39.80
\end{tabular}

\begin{tabular}{ll|ll|ll|ll}
.05 & 102.7 & .90 & 51.83 & .75 & 48.31 & .10 & 39.51
\end{tabular}

\begin{tabular}{ll|ll|ll|ll}
.10 & 100.4 & .95 & 61.31 & .80 & 48.06 & .20 & 39.24
\end{tabular}

\begin{tabular}{ll|ll|ll|ll|}
.15 & 98.20 & 3.00 & 60.79 & .85 & 47.81 & .30 & 38.97
\end{tabular}

\begin{tabular}{ll|ll|ll|ll}
.20 & 96.12 & .05 & 60.29 & .90 & 47.57 & .40 & 38.71
\end{tabular}

\begin{tabular}{ll|ll|ll|ll}
.25 & 94.18 & .10 & 59.80 & .95 & 47.33 & .50 & 38.45
\end{tabular}

\begin{tabular}{ll|ll|ll|ll}
.30 & 92.36 & .15 & 59.33 & 5.00 & 47.09 & .63 & 38.19
\end{tabular}

\begin{tabular}{ll|ll|ll|ll}
.35 & 90.63 & .20 & 58.86 & .05 & 46.85 & .70 & 37.94
\end{tabular}

\begin{tabular}{ll|ll|ll|ll}
.40 & 88.99 & .25 & 58.41 & .10 & 46.62 & .80 & 37.70
\end{tabular}

\begin{tabular}{ll|ll|ll|ll}
.45 & 87.45 & .30 & 57.96 & .15 & 46.40 & .90 & 37.46
\end{tabular}

\begin{tabular}{ll|ll|ll|ll}
.50 & 85.98 & .35 & 57.53 & .20 & 46.17 & 8.00 & 37.22
\end{tabular}

\begin{tabular}{ll|ll|ll|ll}
.55 & 84.58 & .40 & 57.10 & .25 & 45.95 & .10 & 36.99
\end{tabular}

\begin{tabular}{ll|lll|ll|ll}
.60 & 83.24 & .45 & 56.69 & .30 & 45.74 & .20 & 36.77
\end{tabular}

\begin{tabular}{ll|ll|ll|ll}
.65 & 81.97 & .50 & 56.28 & .35 & 45.52 & .30 & 36.55
\end{tabular}

\begin{tabular}{ll|ll|ll|ll}
.70 & 80.76 & 3.55 & 55.88 & .40 & 45.31 & .40 & 36.33
\end{tabular}

\begin{tabular}{ll|ll|ll|ll}
.75 & 79.60 & .00 & 55.49 & .45 & 45.10 & .50 & 36.11
\end{tabular}

\begin{tabular}{ll|ll|ll|ll}
.80 & 78.48 & .65 & 55.11 & .50 & 44.90 & .60 & 35.90
\end{tabular}

\begin{tabular}{ll|ll|ll|ll}
.85 & 77.42 & .70 & 54.74 & .55 & 44.69 & .70 & 35.70
\end{tabular}

\begin{tabular}{ll|ll|ll|ll}
.90 & 75.39 & .75 & 54.37 & .60 & 44.49 & .80 & 35.49
\end{tabular}

\begin{tabular}{ll|ll|ll|ll}
.95 & 75.40 & .80 & 54.01 & .65 & 44.30 & .90 & 35.29
\end{tabular}

\begin{tabular}{ll|ll|ll|ll}
2.00 & 74.45 & .85 & 53.66 & .70 & 44.10 & 9.00 & 35.10
\end{tabular}

\begin{tabular}{ll|ll|lll|ll}
.05 & 73.54 & .90 & 53.32 & .75 & 43.91 & .10 & 34.90
\end{tabular}

\begin{tabular}{ll|ll|ll|ll}
.10 & 72.66 & .95 & 52.98 & .80 & 43.72 & .20 & 34.71
\end{tabular}

\begin{tabular}{ll|ll|ll|ll}
.15 & 71.81 & 4.00 & 52.65 & .85 & 43.53 & .30 & 34.53
\end{tabular}

\begin{tabular}{ll|ll|ll|ll}
.20 & 70.99 & .05 & 52.32 & .90 & 43.35 & .40 & 34.34
\end{tabular}

\begin{tabular}{ll|ll|ll|ll}
.25 & 70.20 & .10 & 52.00 & .95 & 43.16 & .50 & 34.16
\end{tabular}

\begin{tabular}{ll|ll|ll|ll}
.30 & .69 .43 & .15 & 51.69 & 6.00 & 42.99 & .60 & 33.98
\end{tabular} 


\begin{tabular}{rc|rc|rc|rc}
$\begin{array}{r}\text { 時間 } \\
(\mathrm{min})\end{array}$ & $\begin{array}{c}\text { 直径 } \\
(\mu)\end{array}$ & $\begin{array}{c}\text { 時間 } \\
(\mathrm{min})\end{array}$ & $\begin{array}{c}\text { 直径 } \\
(\mu)\end{array}$ & $\begin{array}{c}\text { 時間 } \\
(\mathrm{min})\end{array}$ & $\begin{array}{c}\text { 直径 } \\
(\mu)\end{array}$ & $\begin{array}{c}\text { 時間 } \\
(\mathrm{min})\end{array}$ & $\begin{array}{c}\text { 直径 } \\
(\mu)\end{array}$ \\
.80 & 33.81 & 15.50 & 26.74 & 30.00 & 19.22 & 50.00 & 14.89 \\
.90 & 33.46 & .50 & 25.92 & 32.00 & 18.61 & 60.00 & 13.59 \\
10.00 & 33.29 & 17.00 & 25.53 & 33.00 & 18.33 & 65.00 & 13.06 \\
.20 & 32.97 & .50 & 25.17 & 34.00 & 18.05 & 70.00 & 12.58 \\
.40 & 32.65 & 18.00 & 24.81 & 35.00 & 17.79 & 75.00 & 12.15 \\
.60 & 32.34 & .50 & 24.48 & 36.00 & 17.55 & 80.00 & 11.77 \\
.80 & 32.04 & 19.00 & 24.15 & 37.00 & 17.31 & 85.00 & 11.42 \\
11.00 & 31.74 & .50 & 23.84 & 38.00 & 17.08 & 90.00 & 11.09 \\
.20 & 31.46 & 20.00 & 23.54 & 39.00 & 16.86 & 95.00 & 10.80 \\
.40 & 31.18 & .50 & 23.25 & 40.00 & 16.64 & 100.00 & 10.53 \\
.60 & 30.91 & 21.00 & 22.98 & 41.00 & 16.44 & 110.00 & 10.04 \\
.80 & 30.65 & 22.00 & 22.45 & 42.00 & 16.24 & 120.00 & 9.61 \\
12.00 & 30.39 & 23.00 & 21.95 & 43.00 & 16.05 & 130.00 & 9.23 \\
.50 & 29.78 & 24.00 & 21.49 & 44.00 & 15.87 & 140.00 & 8.89 \\
13.00 & 29.20 & 25.00 & 21.06 & 45.00 & 15.69 & 150.00 & 8.59 \\
.50 & 28.65 & 20.00 & 20.65 & 46.00 & 15.52 & 160.00 & 8.32 \\
14.00 & 28.14 & 27.00 & 20.26 & 47.00 & 15.35 & & \\
.50 & 27.65 & 28.00 & 19.88 & 43.00 & 15.19 & & \\
15.00 & 27.18 & 29.00 & 19.55 & 49.00 & 15.04 & &
\end{tabular}

は表一7〜表一10 作成するのに用いられたつぎの方法 に從って計算する。

(5) $D=\frac{K}{\sqrt{T}}$

ことに:D=直径, $\mu$

$T=$ 沈降時間, $\min$

$T$ は $\min$ 単位であるから, 1 min $の$ 場合は

$$
D=K=91.1 \text {, 炭化珪素 }
$$

$$
\begin{aligned}
& =79.7, \text { 熔融アルミナ } \\
& =81.1, \text { ガーネット }
\end{aligned}
$$$$
=105.3, \text { フリント }
$$

K の計算 :

$$
\begin{aligned}
& \text { 常数 } K=20,000 \sqrt{\frac{9 n L}{2 g(p-d) 60}} \\
& \text { ことに } n=0.00656,25^{\circ} \mathrm{C} \\
& L=100 \\
& g=980 \\
& p=3.22 \text {, 炭化珪素 } \\
& 3.96 \text {, 熔融アルミナ } \\
& \text { 3.85，ガーネット } \\
& \text { 2.61，フリント } \\
& a=0.800,25^{\circ} \mathrm{C}
\end{aligned}
$$

沈降媒の温度が $20^{\circ} \sim 30^{\circ} \mathrm{C}$ の間では, $25^{\circ} \mathrm{C}$ 亿おける Kの值苍つぎのように補正する。

$$
\begin{aligned}
& K, \mathrm{SiC}=109.6-0.741 \times t \\
& K, \mathrm{Al}_{2} \mathrm{O}_{3}=96.16-0.657 \times t \\
& K, \text { ガートト }=98.0-0.675 \times t \\
& K, \text { フリント }=127.1-0.871 \times t \\
& \text { 乙とに: } t=\text { 温度, }{ }^{\circ} \mathrm{C}
\end{aligned}
$$

\section{c. ГОСТ $\left.3647-59^{7}\right)$ について}

研磨材粒度と試験方法に関するこのソヴィエト国家規 格は, ГOCT 3238-46, ГOCT 3647-47，および ГOCT 3648-47の3 規格が改正統合されたもので，1960 年 1 月
1 日に発効し, 粒度呼称（粒度表示記号）に関しては 1 年遅れて 1961 年 1 月 1 日より施行されているものであ る。

改正統合前の上記旧規格において用いられていた粒度 呼称は，280，320，および M 28〜M 5 などの微粉呼称 を除けば，わが国やアメリカなどのそれと一致したもの であったし，その粒度特性もほぼ同様と見做しうる程度 に近似していたといってもよかっだ).

しかし，現行の本規格では粒度呼称の方式を全く変 え，基準粒子残留量を求屯べき適用試験穊の目開き寸法 を $0.01 \mathrm{~mm}$ 単位で表わし, てれを以って粒度呼称の数 值とするように改められた。従って, 粒度を示す数值の 大きなものほどあらく，既述の改正統合前の TOCT， または JIS, SPR, CS, FS, BS……などの粒度呼称の 数值（粒度番号）と全く逆の関係にあり，しか子粒度呼 称を示吉数值の一致しているものが大半以上を占めてい るので, ての点特に注意を要する。

規格内容の主な点を要約して示せばつぎのようであ る。

1）本規格は研磨工具の製造および遊離状態で使用さ れる研磨材に対して適用される。

2）適用対象となる研磨材の種類に 関する規定はな い*.

3）規定粒度およびそれらの類別はつぎのようであ る。

類 別
精 子
粉 粒
微 粉

なおこてで，本規格の付録 1 亿表記されている 0.01 $\mathrm{mm}$ 単位の粒度番号（上記の粒子, 粉粒）とメッシュ No.**住基づくそれとの照合表を転記すればつぎのよう である。

$$
\text { 粒 度 番 号 }
$$

本規格 $(0.01 \mathrm{~mm}$ 単位) $200,160,125,100,80,63,50,40,32,25$, 本規格 $(0.01 \mathrm{~mm}$ 単位) $20,16,12,10,8,6,5,4,3$, メッンュ No. 基準** $10,12,16,20,24,30,36,46,54,60$ $70,80,100,120,150,180,230,280,320$

4）粒度試験方法は粒度番号によって 3 方式が適用さ れる.すなわち，No. 200〜No. 5 は穊分け試験方法に よって, No. M 40〜No. M 5 は顕微鏡による試験方法, または光電管を使用した光透過式沈降粒度測定器によっ て行なう. No. 4 と No. 3 は組合せ試験方法, すなわ ち節分け試験方法と顕微鏡による試験方法の組合せによ って行なう。

5）節分け試験では, 機械的振とう器を用いて所定の 試験節を重亦，試料 $100 \mathrm{~g}$ 专入れ毎分回転数 280 回，衝

* ただし，ダイヤモンドに対してほ別の粒度規格 「OCT 9206-59 ${ }^{11)}$ 占ある.

** 広く各国で慣用され，われわれに馿染夕深い粒度番号と大 体一致しているもの. 
撃数 140 で篩分ける.振とう時間は，No. $200 \sim$ No. 10 に対しては 10 分間, No. 8〜No. 5 に対しては 15 分間 である。

\section{d. FEPA Abrasive Grain Size Standards ${ }^{2}$ につ} いて

この規格は，数年間にわたる FEPA の研磨材委員会 の努力によって 1962 年 1 月に発表されたもので, 国際 標凖化の見地からアメリカの研磨材粒度規格をその基本 としたものである。そして，その序文によれば，專門分 科会の検討の結果，アメリカの結合研磨材料粒度規格は そのまま採択しうることが明らかにされたが，アメリカ の塗装研磨材料粒度規格においては標準砂と絹穊が使用 されており，てれによる独特の試験方法を採択するとと に対しては実際的な困難を伴うことが明白となったの で，てれに対し正確な標準金網穊を以って代光るととも に厳密な許容差を与光ることによって，いわゆる網粒度 (Screen Grades) に適用しうる相当規格を作成提案する に至ったとと，より困難ないわ的穊分け下粒度 (Subsieve Sizes) または々ク口粒度 (Micro-grits) 飞対す る規格の作成提案に関しては，アメリカの Abrasive Grain Association によって国際標集化の見地少引協力 するむねの申出を受けたので，本規格とは別に発行する よう決定したこと，などが本規格の発表に至る経過の大 要である.

つぎに本規格の内容の主な点を要約すると，

1) 本規格は結合研磨材料粒度規格一(8 240 番), 塗 装研磨材料粒度規格一(12 220 番)の 2 規格より成る。

2) 結合研磨材料粒度規格は, 粒度呼称, 適用研磨材 の種類，粒度特性，および穊分け試験方法などに関して SPR 118-50 の表-1 for Grinding Wheels と全く同 じである。

3）塗装研磨材料粒度規格は，CS 217-59 の網粒度 (Screen Grades) に関する規定を基礎として，実体にお いて相当粒度特性が得られるよう節分け試験方法に関し て格別の考慮か泓われている。

4) 塗装研磨材料粒度の道用対象㹥, 熔融アルジ, 炭化珪素, ガーネットの 3 種である. ての点, CS 21759 においてはエメリー，フリントの一部製品に対して も別の粒度特性を規定しているのと異なる。

5） CS 217-59 亿おいて併用されている 6/0，0，1， $41 / 2$ などの粒度呼称に関する記号表示は用いられず，す べて $220,80,50,12$ などの番表示で呼称される.

6）標準砂は CS 217-59の 6.1.1.1 亿表示されてい るアメリカの The Carborundum Co. のものを用い る.

7）塗装研磨材料粒度の試験篩としては U.S. Standard Fine Sieve Series に相当するものを FEPA 標準 節として採用し, 特に ASTM の許容差の半分以内のも
のを選択する。

8）結合研磨材料粒度，塗装研磨材料粒度の䈯分け試 験条件は全々同じで，SPR 118-50 のそれと一致したも のである。

つぎに，本規格所載の結合研磨材料粒度の特性值を 表一11 に, FEPA 標準篩 (ASTM 試験篩) を用い上 記 8)の条件で行なった標準砂の節分析結果を表一12 および塗装研磨材料粒度の特性值を表一13, 表-14 亿 示す.

表一11 結合研磨材料用熔融アルミナおよび炭化珪 素の粒度特性

\begin{tabular}{|c|c|c|c|c|c|c|c|c|}
\hline \multirow[b]{2}{*}{$\begin{array}{l}\text { 粒度 } \\
\text { No. }\end{array}$} & \multirow{2}{*}{$\begin{array}{l}\text { No.1 穊 } \\
\text { 100\% 通過 } \\
\text { しなけれは太 } \\
\text { ならない箁。 }\end{array}$} & \multicolumn{2}{|c|}{ No.2 穊 } & \multicolumn{2}{|c|}{ No.3 箁 } & \multicolumn{2}{|c|}{ No. $3+4$ 篩 } & \multirow{2}{*}{$\begin{array}{l}\text { No.5 穊 } \\
\text { 最大 } 3 \% \text { 通過して } \\
\text { よい䬫 }\end{array}$} \\
\hline & & 篩 & 残留量 & 節 & $\begin{array}{l}\text { 最小 } \\
\text { 残留 } \\
\text { 量\% }\end{array}$ & 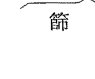 & $\begin{array}{l}\text { 累積最 } \\
\text { 小毘 } \\
\text { 量\% }\end{array}$ & \\
\hline 8 & 6 & 7 & $0-15$ & 8 & 45 & $8+10$ & 80 & 12 \\
\hline 10 & 7 & 8 & $0-15$ & 10 & 45 & $10+12$ & 80 & 14 \\
\hline 12 & 8 & 10 & $0-15$ & 12 & 45 & $12+14$ & 80 & 16 \\
\hline 14 & 10 & 12 & $0-15$ & 14 & 45 & $14+16$ & 80 & 18 \\
\hline 16 & 12 & 14 & $0-15$ & 16 & 45 & $16+18$ & 80 & 20 \\
\hline 20 & 14 & 16 & $0-15$ & 18 & 45 & $18+20$ & 80 & 25 \\
\hline 24 & 16 & 20 & $0-25$ & 25 & 45 & $25+30$ & 70 & 35 \\
\hline 30 & 18 & 25 & $0-25$ & 30 & 45 & $30+35$ & 70 & 40 \\
\hline 36 & 20 & 30 & $0-25$ & 35 & 45 & $35+40$ & 70 & 45 \\
\hline 46 & 30 & 40 & $10-30$ & 45 & 40 & $45+50$ & 65 & 60 \\
\hline 54 & 35 & 45 & $10-30$ & 50 & 40 & $50+60$ & 65 & 70 \\
\hline 60 & 40 & 50 & $10-30$ & 60 & 40 & $60+70$ & 65 & 80 \\
\hline 70 & 45 & 60 & $0-15$ & 70 & 45 & $70+80$ & 70 & 100 \\
\hline 80 & 50 & 70 & $0-25$ & $80^{\circ}$ & 40 & $80+100$ & 65 & 120 \\
\hline 90 & 60 & 80 & $0-15$ & 100 & 40 & $100+120$ & 70 & 140 \\
\hline 100 & 70 & 100 & $0-15$ & 120 & 40 & $120+140$ & 65 & 200 \\
\hline 120 & 80 & 120 & $0-15$ & 140 & 30 & $140+170$ & 60 & 230 \\
\hline
\end{tabular}

\begin{tabular}{|c|c|c|c|c|c|c|c|c|}
\hline & No.1 篩 & $\mathrm{Nc}$ & .2 穊 & No. $3+$ & 4 節 & No. & +5 & $N$ \\
\hline No. & $\begin{array}{l}100 \% \text { 通過 } \\
\text { しなけけれは節 } \\
\text { ならない }\end{array}$ & 篩 & 残留量 & 節 & $\begin{array}{l}\text { 最小 } \\
\text { 残留 } \\
\text { 量\% }\end{array}$ & 穊 & $\begin{array}{l}\text { 累積最 } \\
\text { 小残留 } \\
\text { 量\% }\end{array}$ & 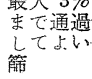 \\
\hline 150 & 100 & 140 & $0-15$ & $170+200$ & 40 & $170+200$ & 23075 & 270 \\
\hline 180 & 120 & 170 & $0-15$ & $200+230$ & 402 & $200+230+$ & -27065 & - \\
\hline 220 & 140 & 200 & $0-15$ & $230+270$ & 40 & $230+270$ & 32560 & - \\
\hline 40 & 170 & 200 & $0-5$ & $230+270$ & 8 & $230+270$ & -32538 & - \\
\hline
\end{tabular}

表一12 FEPA 標準篩を使用した標準砂の篩分析結果 No. 1 穊 No. 2 節 No. 3 節 No.4 節 No.5 穊 No.5 節

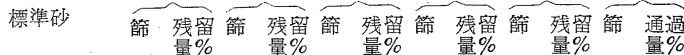

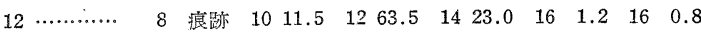

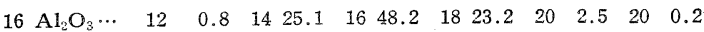

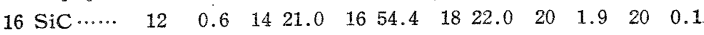
$\begin{array}{llllllllllllll}20 & \ldots \ldots \ldots \ldots & 16 & 0.1 & 18 & 10.3 & 20 & 66.9 & 25 & 21.2 & 30 & 1.4 & 30 & 0.1\end{array}$

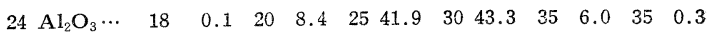

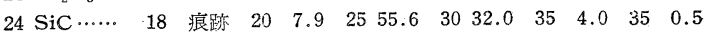

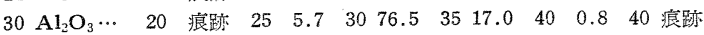

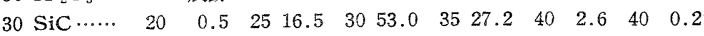

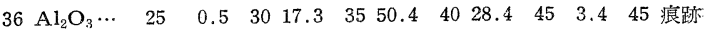

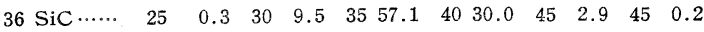

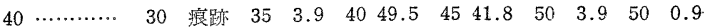

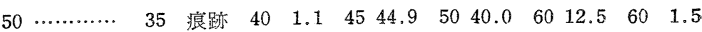
$\begin{array}{llllllllllllll}60 & \ldots \ldots \ldots \ldots & 45 & 0.8 & 50 & 16.1 & 60 & 49.0 & 70 & 23.1 & 80 & 7.6 & 80 & 3.4\end{array}$ $\begin{array}{lllllllllllllll}80 & \mathrm{Al}_{2} \mathrm{O}_{3} \cdots & 50 & 0.0 & 60 & 4.9 & 70 & 26.8 & 80 & 29.8 & 100 & 20.7 & 100 & 17.7\end{array}$

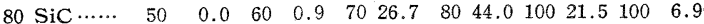
$\begin{array}{lllllllllllllll}100 & \ldots \ldots \ldots \ldots . . & 70 & \text { 痕跡 } 80 & 4.0 & 100 & 23.0 & 120 & 48.5 & 140 & 20.6 & 140 & 3.9\end{array}$ $\begin{array}{lllllllllllllll}120 \ldots \ldots \ldots \ldots & 80 & 0.1 & 100 & 1.2 & 120 & 17.8 & 140 & 56.3 & 170 & 19.7 & 170 & 4.9\end{array}$ $\begin{array}{lllllllllllll}150 \cdots \ldots \ldots \ldots & 120 & 0.2 & 140 & 16.7 & 170 & 42.8 & 200 & 34.2 & 230 & 5.5 & 230 & 0.6\end{array}$ $\begin{array}{llllllllllllll}180 & \mathrm{Al}_{2} \mathrm{O}_{3} & 140 & 0.9 & 170 & 12.6 & 200 & 44.4 & 230 & 28.8 & 270 & 8.3 & 270 & 5.0\end{array}$

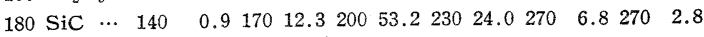
$220 \ldots \ldots \ldots \ldots .170 \quad 0.2200 \quad 18.9230 \quad 44.3 \quad 270 \quad 18.4 \quad 325 \quad 13.2 \quad 325 \quad 5.0$ 
表一13 塗装研磨材料用熔融アルミナの粒度特性

\begin{tabular}{|c|c|c|c|c|c|c|c|c|c|}
\hline \multirow[b]{2}{*}{ No. } & No.1 節 & \multicolumn{2}{|c|}{ No.2 穊 } & \multicolumn{2}{|c|}{ No.3 節 } & \multicolumn{2}{|c|}{ No. $3+4$ 節 } & \multicolumn{2}{|c|}{ No.5 篩 } \\
\hline & 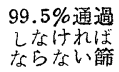 & 節 & $\begin{array}{c}\text { 残留量 } \\
\text { 严 }\end{array}$ & 節 & $\begin{array}{c}\text { 残留量 } \\
\text { \% }\end{array}$ & 穊 & $\begin{array}{l}\text { 罾積残留 } \\
\text { 等 }\end{array}$ & 節 & $\begin{array}{c}\text { 通過量 } \\
\%\end{array}$ \\
\hline 12 & 8 & 10 & $7-17$ & 12 & $53-73$ & $12+14$ & $73-93$ & 16 & $0-3$ \\
\hline 16 & 12 & 14 & $20-30$ & 16 & $38-58$ & $16+18$ & $60-80$ & 20 & $0-3$ \\
\hline 20 & 16 & 18 & $5-15$ & 20 & $57-77$ & $20+25$ & $75-95$ & 30 & $0-3$ \\
\hline 24 & 18 & 20 & $3-13$ & 25 & $32-52$ & $25+30$ & $75-95$ & 35 & $0-3$ \\
\hline 30 & 20 & 25 & $1-11$ & 30 & $67-87$ & $30+35$ & $79-99$ & 40 & $0-3$ \\
\hline 36 & 25 & 30 & $12-22$ & 35 & $40-60$ & $35+40$ & $68-88$ & 45 & $0-3$ \\
\hline 40 & 30 & 35 & $0-10$ & 40 & $40-60$ & $40+45$ & $80-100$ & 50 & $0-3$ \\
\hline 50 & 35 & 40 & $0-10$ & 45 & $35-55$ & 45 & & 60 & $0-3$ \\
\hline 60 & 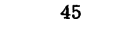 & 50 & $11-21$ & 60 & $39-59$ & $60+70$ & $62-82$ & 80 & $0-5$ \\
\hline 80 & 50 & 60 & $0-10$ & 70 & $17-37$ & $70+80$ & $47-67$ & 100 & $13-23$ \\
\hline 100 & 70 & 80 & $0-10$ & 100 & $13-33$ & $100+120$ & $62-82$ & 140 & $0-10$ \\
\hline 120 & 80 & 100 & $0-10$ & 120 & $8-28$ & $120+140$ & $64-84$ & 170 & $0-10$ \\
\hline 150 & 120 & 140 & $12-22$ & 170 & $33-53$ & $170+200$ & $67-87$ & 230 & $0-3$ \\
\hline 180 & 140 & 170 & $8-18$ & 200 & $34-54$ & $200+230$ & $63-83$ & 270 & $0-10$ \\
\hline 220 & 16 & 200 & & & & & & 32 & \\
\hline
\end{tabular}

表一14 塗装研磨材料用炭化珪素およびガーネットの 粒度特性

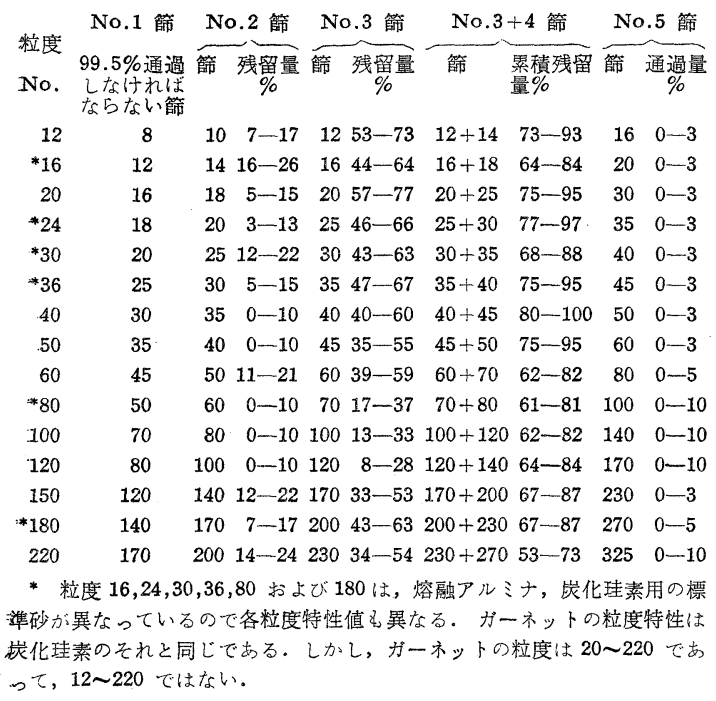

\section{e. ダイヤモンドの粒度規格につ(てて 91,10$), 11)$}

ダイヤモンドの粒度規格として，CS 123-4999，BS $1987: 1953^{10)}$ ，ГOCT 9206-5911) などが知られている が，乙れらの各規格においては粒度呼称 (表示記号), 粒度特性規定值などがそれぞれ異なるとともにいずれも 熔融アルミナ，炭化珪素などのそれとも異なっている。

つぎに，各規格における規定粒度および試験方法など の大要を記すと，

1） CS 123-49 の粒度の類別は，ミクロンサイズ (micron sizes) 8 種粒度, 節サイズ (sieve sizes) 7 種 粒度で計 15 種類の粒度が規定されている. 粒子径は粒 子の最も長い径とこれに直交する径のうちで最も長い径 の和の $1 / 2$ で示す。この二軸平均径で表わす方法は JIS R 6002-1956 の方法と全く同じである.

2） BS 1987:1953 の粒度の類別は，節下サイズ（subsieve size) 9 種粒度，節サイズ (sieve size) は BS 410 標準試験篩によるもので，a. 広域分粒粒度 (wide grad- ing）として 12/16〜240/350 の 10 種粒度, b. 狭域分 粒粒度 (close grading) として 12/14 300/350 の 20 種 粒度か涀定されている。節下サイズは顕微鏡によって測 定するが，粒子径は粒子の投影面積を一連の円の面積と 比較して示すいわゆる円形相当径で表わすとととしてい る.

3） ГOCT 9206-59 の粒度は既述の ГOCT 3647-59 と似た粒度呼称で表わし，その粒子および粉粒に相当す るものとして A 50〜A 4 の 12 種粒度, 微粉に相当す るものとしてはAM 40 AM 1 の 9 種粒度, 計 21 種類 の粒度が摫定されている. 粒度試験はすべての粒度にわ たって顕微鏡によって行ない，その粒子径は JIS R 6002-1956, CS 123-49 と全く同様の方法すなわち二軸 平均径で表わし, A 50〜A 4 の粒度は 300 個以上, AM 40〜AM 1 の粒度は 500 個以上を測定することなどが規 定されている.

\section{f. 研磨布紙の規格に粒度が規定されているもの ${ }^{12), 13)}$}

研磨布紙の規格において粒度の特性值を規定したもの につぎのような規格がある。

その1つはアメリカのクローカスクロスに関する規格 で，これにおいて酸化鉄の粒度 (粉末度) が規定されて いる。

ての規格に関しては b.の3.1.2.4にも記載されてい るが，現行規格はFS P-C-458 $a^{12)}$ (Amendment-1) May 25, 1956 である.

他は BS 871：1961 ${ }^{13)}$ で，乙の規格は A. Emery Cloth, B. Glass Paper, C. Glass Cloth, D. Sheet Flint Paper の4 部から構成されており，それぞれにお いて研磨材すなわちエメリー，ガラス，卦石またはフリ ントなどの粒度呼称 (表示記号) とそれぞれの BS 410 標準試験穊による粒度特性值か涀定されている。乙れら の粒度呼称, 粒度特性規定值は CS 217-59 そおいて規 定されているエメリー，フリントのそれとは全く異な る・

\section{g. 試験篩の規格の改正について}

既述の SPR 118-50, CS 217-59, FEPA Abrasive Grain Size Standards, CS 123-49, FS P-C-458 a な ぞにおいて用いられている U.S. 標準篩 (ASTM 試験 穊) は ASTM E 11-39 (1939〜1958 Standard, 1958〜 1961 Tentative) に基づくものであるが，てれは改正さ れ ASTM E 11-61 14) (1961 Standard) となった.（こ れと関連して ASA Z 23.1 15) も改正された). この改 正による上記各粒度規格の粒度特性值に与える影響は実 質上無視しうる程度のものであるが，現時点において上 記各粒度規格はいずれもこの ASTM, ASA の改正を折 込んでいないととに留意すべきである。

一方，イギリスにおいても既述の BS 1987 : 1953, BS 871 : 1961 で用いられている試験節の規格-BS 410 : 
研磨材の種類および用途の種別***

\begin{tabular}{|c|c|c|c|c|c|c|c|c|c|c|c|c|c|c|c|c|c|c|c|c|c|c|c|}
\hline & \multirow{3}{*}{ 国 } & \multirow{3}{*}{\multicolumn{2}{|c|}{ 別 }} & \multirow{3}{*}{ 規 } & \multicolumn{19}{|c|}{ 糧類推 } \\
\hline & & & & & \multicolumn{3}{|c|}{$\begin{array}{l}\text { 熔融アル } \\
\text { 今 }\end{array}$} & \multicolumn{3}{|c|}{$\overbrace{}^{\text {岸化珪素 }}$} & \multicolumn{2}{|c|}{$\begin{array}{l}\text { ダイヤモ } \\
\text { ンド }\end{array}$} & \multicolumn{2}{|c|}{$\begin{array}{l}\text { ガーネ } \\
\text { ット }\end{array}$} & \multicolumn{2}{|c|}{ エメリ } & \multicolumn{2}{|c|}{ 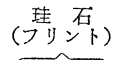 } & \multicolumn{2}{|c|}{$\overbrace{}^{\text {ガラス }}$} & \multicolumn{2}{|c|}{$\overbrace{}^{\text {酸化鉄 }}$} & \multirow[t]{2}{*}{ その他 } \\
\hline & & & & & B & $\widehat{\mathrm{C}}$ & $P$ & $\mathrm{~B}$ & $\mathrm{C}$ & 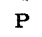 & $\overparen{B}$ & $\widehat{C P}$ & $\widetilde{C}$ & $\vec{P}$ & $\widetilde{\mathrm{C}}$ & $P$ & $\overparen{\mathrm{C}}$ & P & $\mathrm{C}$ & $\mathbf{P}$ & $\mathrm{C}$ & $\mathbf{P}$ & \\
\hline 日 & & & 本。 & JIS R 6001-1956 & 0 & 0 & 0 & 0 & 0 & 0 & 0 & 00 & 0 & 0 & 0 & 0 & O & O & 0 & 0 & 0 & O & 0 \\
\hline$P$ & x & リ & カ & SPR $118-50$ & O & & O & 0 & & 0 & & & & & & & & & & & & & \\
\hline$ア$ & $x$ & リ & カ & CS $217-59$ & & O & & & 0 & & & & 0 & & $\Theta$ & & $\Theta$ & & & & & & \\
\hline$ア$ & $x$ & y & カ & CS $123-49$ & & & & & & & 0 & 00 & & & & & & & & & & & \\
\hline$P$ & $x$ & リ & 力 & FS P-C -458 a & & & & & & & & & & & & & & & & & 0 & & \\
\hline 欧 & ギリス & 者含 & & $\operatorname{FEPA}(\mathrm{B})^{* * *}$ Std. & 0 & & & 0 & & & & & & & & & & & & & & & \\
\hline & ギリス & 含在 & & FEPA $(\mathrm{C})^{* * *}$ Std. & & O & & & 0 & & & & 0 & & & & & & & & & & \\
\hline 1 & ギ & y & z & BS $871: 1961$ & & & & & & & & & & & 0 & & O & & 0 & & & & \\
\hline 1 & $\neq$ & y & र & BS $1987: 1953$ & & & & & & & 0 & 00 & & & & & & & & & & & \\
\hline ソ & ヴ 1 & $I$ & 卜 & ГОСТ $3647-59$ & 0 & 0 & 0 & 0 & 0 & 0 & & & 0 & 0 & 0 & 0 & 0 & 0 & 0 & 0 & 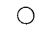 & O & 0 \\
\hline ' & ヴ 1 & $I$ & ト & ГОСТ 9206-59 & & & & & & & & 00 & & & & & & & & & & & \\
\hline
\end{tabular}

1943一が ISO 24 専門委員会の活動とアメリカの規格一 ASA Z 23.1-1961, ASTM E 11-61-の改正を考慮し て改正され，SB $410: 1962^{16)}$ として 1962 年 12 月 31 日に発行された.イギリスの場合も現行の上記粒度規格 はこの試験篩規格の改正を折込んでいないので，ての点 留意すべきである。

\section{III. 研磨材の種類亡用途別による粒度体系}

以上，いくつかの研磨材粒度規格について述べてきた が，各規格において対象としている研磨材の種類または 用途の類別を総括して示すと, 表一15 のようになる.

表一15 から直ちに明らかなととは，適用範囲がすべ ての研磨材および研磨材製品または用途に及ぶと見做せ る規格は JIS のみで，JIS とやや似た方式の規格は ГOCT であるが，乙れとてもダイヤモンドに対しては 別の ГOCT によっているととである.

また，各規格の内容をII. で述べた点に従って見てみ ると,アメリカでは研削砥石用(熔融アル之ナ, 炭化珪 素：粒度特性同一)-SPR 118-50 表一1, ポリッシング 用 (熔融アルミナ，炭化珪素 : 粒度特性同一) - SPR 118-50 表-2, 研磨布紙 (熔融アルミナ, 炭化珪素, ガ 一ネット,エメリー,フリント, 酸化鉄 : 粒度特性は研 磨材の種類または製品別によって同一ではない）-CS 217-59; FS P-C-458 a (1)，ダイヤモンドーCS 123-49 のように, 研磨材の種類および研磨材製品別または用途 別によってそれぞれ別の粒度特性による規格を準備制定 している・イギリスもアメリカと同様な考えの上に立脚 して粒度規格を制定してきた点はその研磨材製品の粒度 規格の上に反映されているとてろから知るてとができ る。

主たる先進研磨材料工業国であるアメリカ，イギリス などの研磨材粒度の規格体系が多元的であるととの主な 理由は, 過去一世紀より現在に至る永年にわたる各種研
磨材製品の粒度に関する慣習による点が支配的であるこ とによるものと考朰れる．乙の点に関しては，さらに アメリカ，イギリスなどの過去の粒度規格について併せ 検討考察を加えるときなおいっそう明瞭であって，てれ らの歴史的事実を無視することなく，国際標準化の見地 から各国における粒度の多様的である点を具体的に克服 し, 簡潔な個条書的, 表記的の記述として発表された FEPA の研磨材粒度規格の内容は, 二大研磨材製品であ. る結合研磨材料および塗装研磨材料に対する粒度規格と して現在最も勝れた規格であると考えて差支えないと思 われる。

研磨材の粒度そのものは，元来研磨材の大きさを表わ す民度であるから，国際的に同一尺度であるととが最も 望ましいととであることは当然のととというべきである が，以下別の観点から研磨材粒度に関して若干考察を加 えてみたい。

多くの研究報告や経験的事実などによって，研磨材お よび研磨材製品の加工時における作用機構はそれら自体 の性状と加工物や作用条件などが複雑にからみ合って， 目的とする加工能率や加工面の性状に対して非常に大き な影響を与えることがよく知られている。そして，研磨 材料一般において最も根本的な問題である研磨材の基本 的性質のうちで，粒度で表わされる寸法的特性となお現 在未知に属する点の非常に多い硬度, 靯性, 磨滅抵抗な どによって表わされる物性的特性に関しては, 従来なら びに最近比較的よく論議研究されてきたが，粒子形状， 尖鋭度などの形状的特性に関してはそのような事例が極 めて少ないように思われる。

しかし，乙の形状的特性と粒度で表わされる寸法的特 性は同時相関的の特性であるから, 粒度について問題と するときにはその粒子形状，尖鋭度などをも同時に考虑 しなければならないととは当然のととと考光られ，また 三次元の研磨材粒子を二次元的に測定する粒度試験方法 
のもつ宿命的な欠陷に帰因する粒度の不確定性について は単に測定精度の面からではなく，別の見地からも検討 すべき問題があるように考觉られる。例えば，代表的な 例として，三次元的構造をもつ結合研磨材料と二次元的 構造をもつと見做せる塗装研磨材料の作用機構に適合し た構造的理想像を，研削作業を前提とし，研磨材の物性 的特性を一応無視して考えれば，前者に適した粒子形状 は完全球形にできるだけ近いもので，しかも充分な尖鋭 度をもつものであるとと, 後者特に電着法(静電叙装法) 亿よるそれに適した粒子形状は適当に細長いもので充分 な尖鋭度を経時的に新生しうるものであるてとなどが容 易に理解でき，乙の場合単に形状特性だけを問題とする ならば実用上，形状指数，篙比重などを考慮すること亿 よって一応目的を達するととができる。しかし，ててで 先にふれたように形状特性と粒度とは同時相関的な関係 そあることと粒度試験方法のもつ不可避的な欠陥を考元 て，目的に適合した形状特性をるつ研磨材に対してはそ れぞれ相当範囲の粒度特性值を与えなければ不適当と考 えられる。てのような観点から，研磨材の粒度は使用目 的によってその特性值が相当程度変ったものがいくつか 与光られて然るべきであると思われる。

以上述べてきた点を総括して, 望ましい粒度の規格体 系としての問題点はつぎのような諸点であろうと考えら れる。

1）歴史的地域的慣習を考慮しているか

2）国際標準化の方向と一致したものであるか

3）外国粒度規格の改正に直ちに即応できる内容およ び体系を備えているか

4）試験方法が適当であるか

5）試験節の規格など関連規格の国際性は充分である 加

6）研磨材の種類および使用目的を考慮したものであ るか

\section{IV.むすび}

以上, 研磨材粒度の外国規格の簡単な解説を主とし, 最近の国際標準化の方向ならびに現時点において望まし 心と考えられる体系らしきものについて述べた。
途中省略してわかりにくくした点（例壳ば，各国粒度 規格の詳細な比較検討, 現行の JIS R 6001 3 の内容 に対する考察などのごとき）もあり，意を達し得たか不 かを疑うものであるが，幸佂研磨材および研磨材製品の 輸出入上などの実際面に関して何等かの参考となり得れ ば幸いである，そして，また大方の理解を得て不十分な 点，誤った点などの御指摘を得ることができれば幸いと 考えているものである.

本稿を草するに当り，研磨布紙協会の後藤仙三氏と Coated Abrasives Manufacturers' Association の S.G. Burgess 氏 から FEPAの規格に関する情详を戴いた。 ここに付記して感 謝の意定表する。

\section{文献}

1) SPR 118-50, Abrasive Grain Sizes. 1950.

2) FEPA : Abrasive Grain Size Standards. The Abrasive Industries Association, London, 1962.

3) FEPA : Standard Dimensions for Coated Abrasives. Coated Abrasives Manufacturers' Association, London, 1962.

4）橋本謙一, “砥粒の粒度について”, 大日本案業協会雑誌, 51 [607] 435-39 (1943).

5）遠藤幸雄, “研磨材粒度, 特に研磨布紙の粒度について”, 金属, 24 [8] 643-47 (1954).

6) CS 217-59, Grading of Abrasive Grain on Coated Abrasive Products. 1959.

7) ГОСТ 3647-59, Абразивные материалы в зерне. Классификация по крупности, нормы зернового состава и методы испытаний. 1959.

8) E.N. Masslow, "Körnung der Schleifmittel"; pp. 40-43, Grundlagen der Theorie des Metallschleifens. Verlag Technik, Berlin, 1952. 196 pp.

9) CS 123-49, Grading of Diamond Powder. 1949.

10) B.S. $1987: 1953$, Classification of Diamond Powder in the Sieve and Sub-Sieve Ranges. 1953.

11) ГОСТ 9206-59, Порошки адмазные. 1959.

12) FS P-C-458 a (1), Cloth, Abrasive, Crocus. 1954. (Amendment-1, 1956).

13) B.S. $871: 1961$, Specification for Abrasive Papers and Cloths for General Purposes. 1961.

14) ASTM E 11-61, Standard Specifications for Sieves for Testing Purposes (Wire Cloth Sieves, Round. Hole and Square-Hole Plate Screens or Sieves). 1961.

15) ASA Z 23.1-1961, Standard Specifications for Sieves for Testing Purposes. 1961.

16) B.S. $410: 1962$, Specification for Test Sieves. 1962. 